\title{
A Comparison of the Composition and Diversity of Tree Populations along a Hydrological Gradient in Floodplains (Southern Québec, Canada)
}

\section{Jean-Sébastien Berthelot ${ }^{1}$, Diane Saint-Laurent ${ }^{1,2, *}$, Vernhar Gervais-Beaulac ${ }^{1}$ and Aurélien Présent ${ }^{3}$}

1 Département des Sciences de L'Environnement, Université du Québec à Trois-Rivières, 3351 Boulevard des Forges, Trois-Rivières, QC G9A 5H7, Canada;

E-Mails: jean-sebastien.berthelot@uqtr.ca (J.-S.B.); vernhar@gmail.com (V.G.-B.)

2 Géographie et Laboratoire de Recherche en Géomorphologie Fluviale et Sols, Université du Québec à Trois-Rivières, 3351 Boulevard des Forges, Trois-Rivières, QC G9A 5H7, Canada

3 Lyonnaise des Eaux, Direction Rhones-Alpes-Auvergne, 988, Chemin Pierre-Drevet, 69147 Rillieux-la-Pape, France; E-Mail: present.aurelien@gmail.com

* Author to whom correspondence should be addressed; E-Mail: diane.saint-laurent@uqtr.ca; Tel.: +1-819-376-5011 (ext. 3674); Fax: +1-819-376-5112.

Academic Editors: Philip J. Polglase and Eric J. Jokela

Received: 17 October 2014 / Accepted: 19 March 2015 / Published: 30 March 2015

\begin{abstract}
With the current climate changes, it is essential to understand the mechanisms that govern floods and flow regimes and their effects on the dynamics of riparian forests. The aim is to assess the effects of new hydrological conditions (increase in flood frequency) on forest stands subject to frequent floods. The sampling sites (total of 94 quadrats) are located in riverine woodlands, and the choice of location corresponds to the boundaries of the flood-risk zones established by official government maps. Our study shows that there are significant differences in the composition and diversity of forest communities following differences in the flood recurrence zones. In the active floodplains (i.e., recurrence interval of 0-20 years), the tree population stands are clearly distinguished from other intermediate flood zones (interval of 20-100 years). Differences are also noted in the structure of the communities, in particular in the frequent flood zones, which are characterized by a low renewal rate, low density and less-diversified forest stands. The frequent floods risk forest stand rejuvenation and creating decline as a result of increased tree mortality and the low renewal
\end{abstract}


rate. With the expected increases in the number of flood events in the coming decades, there may be greater tree mortality and a gradual disappearance of the forest communities.

Keywords: active floodplains; composition and structure; hydrological gradient; riparian forests

\section{Introduction}

A number of studies have dealt with variations in the water regime and their effects on the composition and vitality of riparian ecosystems [1-3]. With global warming, it is known that these impacts can vary at the local and regional levels, as well as based on the type of catchment and flow regime $[3,4]$. The hydroclimatic variations (e.g., river flow, temperature and rainfall) related to global warming could thus induce major changes in flow regimes and riparian ecosystems [4-6]. Also, river regulation has a direct impact on river flow, which in turn can have an adverse effect on the vitality of riparian ecosystems [6,7]. Among the many factors that regulate the structure of wetland communities and plants, environmental heterogeneity easily stands out as the key factor. Heterogeneity in wetlands is created and maintained mainly through the interaction between hydrology and geomorphology [8-11]. Various authors [9,12-15] have shown that patterns of species richness and floodplain productivity are significantly influenced by physical factors (e.g., drainage, floods, fires) and by the processes operating on the lateral, longitudinal and vertical dimensions of rivers. Topographic elevation appears to be the key variable that accounts for the vegetation composition of several riverside environments [16-18]. Land elevation affects flood rate and duration, for instance. Sites with an average elevation that are flooded on an intermediate basis are usually those with the richest plant species. Some studies on species richness, conducted along the rivers' longitudinal axis (upstream-downstream), have shown that the greatest richness is most often found on the sites of floodplains with a greater variability of substrate $[14,19,20]$.

Riparian ecosystems are known to be critical environments for maintaining biodiversity. Floods are also generally considered active factors in the enrichment of floodplain ecosystems (e.g., fine sediments, transport of seeds, organic particles, nutrients), especially along rivers crossing through wetlands, marshes or forests [21-23]. The concentration of these various elements (e.g., humus, nitrogen, phosphorus) in the riparian environment is used as an indicator of soil fertility and the vitality of plant life in fluvial environments [23-25]. However, certain studies report that changes in the water regime, in particular an increase in heavy floods, have a direct impact on the vitality of riparian populations [26-28]. Heavy or frequent floods can result in the premature demise of trees found in low river terraces [26].

Various studies stress the role of disturbances in the development and maintenance of a rich vegetation mosaic $[6,13,14]$. In riparian environments, one of the greatest disturbances results from flood dynamics $[4,9,14]$. Different intensities of flood events over time and space can create a mosaic involving successive stages $[28,29]$ since the various plant species have different levels of tolerance to disturbances and variations in the hydrological regime (floods vs. drought), as well as different competitive abilities. Factors such as frequency, season, duration, flood extent, flood period and seasonality contribute to the variability observed in wetland riparian communities [30-34]. 
Despite substantial scientific literature on climate change and its impact on flow regimes, very few authors have studied the impact of increased floods on the composition, diversity and structure of riparian forest populations. Frequent flooding can also disrupt pedogenetic processes and biogeochemical cycles and could alter the development of riparian vegetation [35-37]. For instance, organic matter (e.g., leaves, twigs, dead plants) can accumulate in the soil during the growing and fall seasons, but could be transported further downstream during flooding, thus causing soil degradation and depriving the vegetation of essential nutrients (e.g., carbon, nitrogen, phosphorus). Studies conducted in southern Québec watersheds show that successive flooding results in soil depletion, which could adversely affect riparian ecosystems [35-37], particularly with respect to the regeneration of trees in the riparian areas. Increased recurrence of flooding may also result in floodplain vertical aggradation and a loss of nutrients. For the basins in south-central Québec, no studies have yet been done to determine the impact of frequent floods on the composition and structure of riparian forest populations. It is therefore important to gain a better understanding of the impact of successive floods on the vitality and preservation of the tree populations under these water regime conditions.

In this study, we examined the tree population dynamics in riparian environments affected by floods. The sampling stations are found in two major watershed basins in southern Québec, i.e., the Massawippi and Saint-François rivers. More specifically, the aim was to assess the impact of increased flooding on the composition, diversity and structure of tree populations in riparian areas. Tree species were inventoried according to the different flood zones that appear on official government maps $[38,39]$, and include two main zones, i.e., flood zone with recurrence interval of 0-20 years and a second zone with recurrence interval of 20-100 years. The zones outside the floodplain but near the riverbanks were also considered in this study.

\section{Methods}

\subsection{Study Area}

The study areas were located along the Massawippi River (MAS) and the mid-section of the Saint-François River (STF), between the Sherbrooke and Drummondville sectors, and which occupy the large Saint-François river catchment in south-central Québec (Figure 1). The two rivers are characterized by large flat floodplains interspersed with agricultural areas, forests or woodlands and urban areas (e.g., Windsor, Richmond and Drummondville). These two rivers (MAS and STF) contain river sections considered as flood-risk zones for which official government maps have been created [38,39]. Table 1 shows some hydrological data for the Massawippi and Saint-François rivers, which differ in particular through their width, length and flow regime. For instance, the mean annual discharge in the Saint-François River is $206 \mathrm{~m}^{3} \cdot \mathrm{s}^{-1}$, and the peak discharge is $2719 \mathrm{~m}^{3} \cdot \mathrm{s}^{-1}$. The mean annual and peak discharges of the Massawippi River are significantly lower, i.e., $10 \mathrm{~m}^{3} \cdot \mathrm{s}^{-1}$ and $135 \mathrm{~m}^{3} \cdot \mathrm{s}^{-1}$, respectively [39]. 
The soils in the alluvial plains consist mainly of Regosol, Gleyed Regosol and Brunisolic soils [35,36,40], with a mineral matrix mainly characterized by fine sediments (silt and fine sand) and drainage classified poor to moderately good [40]. Outside of the floodplains, the soil types are mostly Brunisolic and young Podzolic, consisting of a matrix mainly characterized by sand (fine or medium sand) that may contain gravel and a few blocks, with generally good or excessive drainage in sloped areas (Table 2). The forests in the study area are part of the sugar maple-basswood bioclimatic subdomain. The tree populations along the rivers are characterized by stands of red ash and black ash (Fraxinus pennsylvanica Marsh., F. nigra Marsh.), and silver maple (Acer saccharinum L.). The areas outside the floodplains are mainly characterized by mixed stands made up of red maple (Acer rubrum L.), sugar maple (Acer saccharum L.), balsam fir (Abies balsamea Mill.), and hemlock (Tsuga canadensis L.).

The vast majority of the original forests have disappeared with the arrival of the first settlers in the late 19th century. Their arrival in the region with the construction of the first sawmills owned by forestry companies have increased and intensified woodland clearing, thereby modifying the original forests and riverine environment in just a few decades [41]. After several years of intensive clearing for lumber and farming purposes, there were concerted efforts on the part of the Quebec Department of Lands and Forests and local authorities between 1940 and 1950 to step up riverbank reforestation, especially along the Saint-François River, which had been identified as a priority area for flood risk control purposes. Many periodically flooded areas have been left uncultivated and, since 1945 and especially 1950, there has been an expansion of woodlands in some riverside areas (e.g., Richmond and Windsor), while other areas (e.g., Sherbrooke) saw a greater loss in woodlands. For instance, the measured gains (woodlands) were about $12,183.1 \mathrm{~km}^{2}$ and the losses $733.7 \mathrm{~km}^{2}$ in the middle reaches of the Saint-François River from 1945-2000 [41].

\subsection{Floods and Hydrological Data}

Part of the study consisted in performing an exhaustive search of available government and historical flood data and of drawing up a chronological compilation of the events. The historical reconstruction of flood events in the study area was done using data obtained from different sources. The flood inventory was done using flood records and other documents, including reports from the Quebec Streams Commission, a review of various regional and local newspapers, flood records from Quebec's Department of Public Safety, and CIEQ databases (UQTR), as well as regional monographs and published papers. The hydrologic variables selected for the study include the annual mean flow, the monthly mean flow, and the annual maximum daily flow (peak discharge). The hydrological data were obtained from government databases [38,39]. The gauging stations retained for the study are located along the Saint-François and Massawippi rivers (Table 1). 


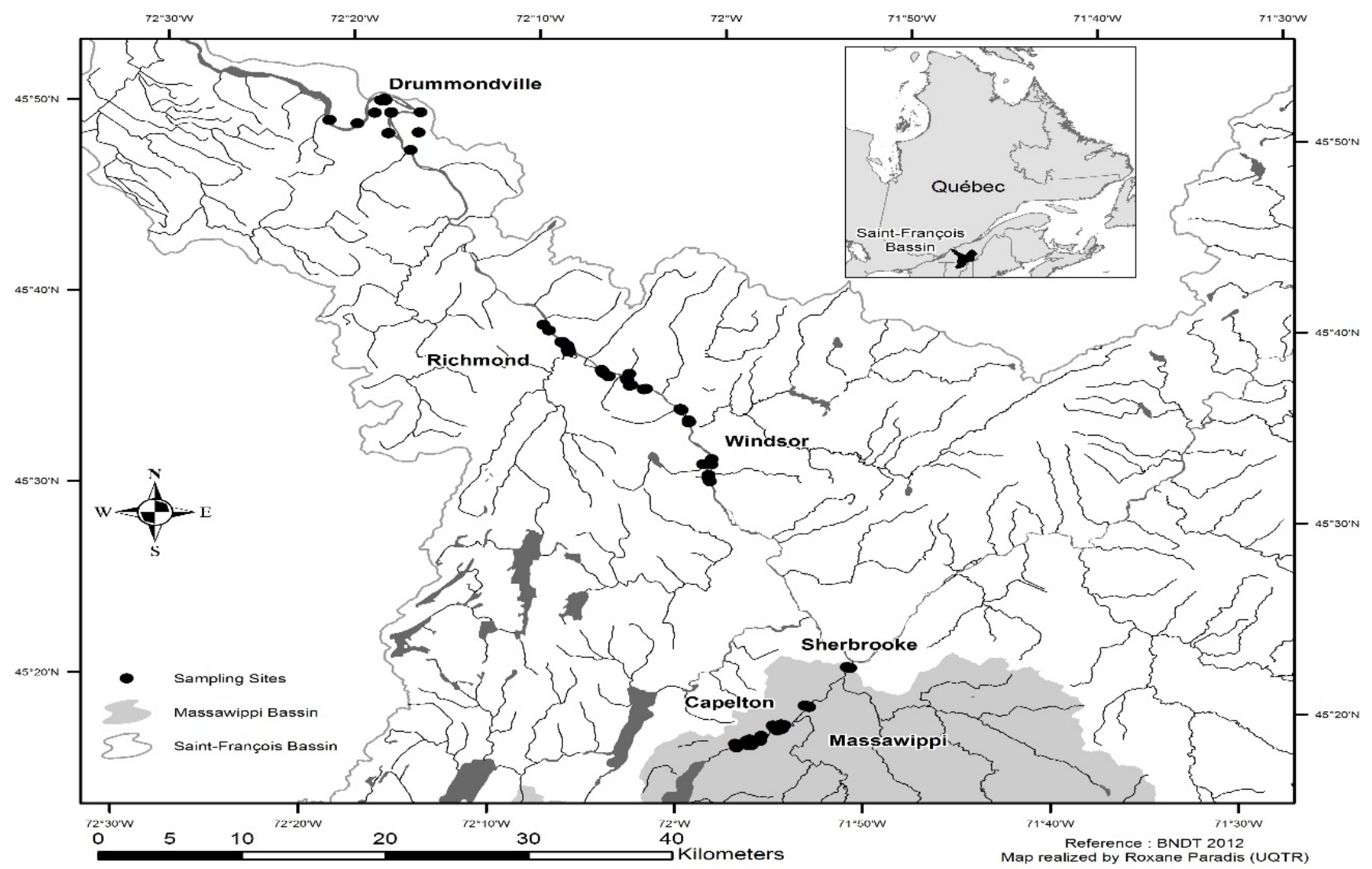

Figure 1. Location of sampling sites along the Massawippi (MAS) and Saint-François rivers (STF), in southern Québec, Canada. The watershed of Massawippi River appears in gray color on the map.

Table 1. Hydrological data from gauging stations located in the François River Basin (Southern Québec, Canada).

\begin{tabular}{cccccc}
\hline $\begin{array}{c}\text { River Sectors Massawippi } \\
\text { (MAS) Saint-François (STF) }\end{array}$ & $\begin{array}{c}\text { Massawippi } \\
\text { (MAS) }\end{array}$ & $\begin{array}{c}\text { Sherbrooke } \\
\text { (STF) }\end{array}$ & $\begin{array}{c}\text { Windsor } \\
\text { (STF) }\end{array}$ & $\begin{array}{c}\text { Richmond } \\
\text { (STF) }\end{array}$ & $\begin{array}{c}\text { Drummondville } \\
\text { (STF) }\end{array}$ \\
\hline Gauging stations & 02 OE019 & 02 OE005 & 02 OF004 & 02 OF001 & 02 OF002 \\
Period observed & $1952-1996$ & $1919-2011$ & $1936-1972$ & $1915-1965$ & $1960-2010$ \\
Mean channel width (m) & 30 & 140 & 180 & 180 & 260 \\
Mean channel height (m) & $1-1.5$ & $1-1.5$ & $1-2$ & $1-2$ & $1-3$ \\
River bed (depth in m) & $1.5-4$ & $4-8$ & $4-6$ & $3-5$ & $4-8$ \\
Mean annual discharge (m $\left.{ }^{3} / \mathrm{s}\right)$ & 10 & 101 & 165 & 183 & 205 \\
Peak discharge (ms) & 135 & 1553 & 2080 & 2080 & 2719 \\
Flood occurrence & 37 & 61 & 27 & 44 & \\
$\quad$ (return period) & & & & 22.6 & \\
Land uses: Farmlands (\%) & 29.1 & 37.0 & & 69.7 & 46.0 \\
Forest areas (\%) & 68.5 & $<31.0$ & & 0.8 & 47.1 \\
Urban areas (\%) & 0.8 & 31.3 & & 3.6 \\
\hline
\end{tabular}


Table 2. Biophysical variables measured in the quadrats ( 94 in total) in different flood zones and no-flood zones along the Massawippi (MAS) and Saint-François (STF) rivers in southern Québec, Canada.

\begin{tabular}{|c|c|c|c|c|c|c|c|}
\hline \multicolumn{2}{|r|}{ Biophysical variables } & \multicolumn{3}{|c|}{ MAS Sector } & \multicolumn{3}{|c|}{ STF Sector } \\
\hline Variable & Variable Description & $\begin{array}{c}\text { Flood } \\
\text { Recurrence } \\
\text { (0-20 years) }\end{array}$ & $\begin{array}{c}\text { Flood } \\
\text { Recurrence } \\
(20-100 \text { years })\end{array}$ & $\begin{array}{l}\text { Outside of } \\
\text { the } \\
\text { Floodplains }\end{array}$ & $\begin{array}{c}\text { Flood } \\
\text { Recurrence } \\
(0-20 \\
\text { years }) \\
\end{array}$ & $\begin{array}{c}\text { Flood } \\
\text { Recurrence } \\
\text { (20-100 years) }\end{array}$ & $\begin{array}{c}\text { Outside } \\
\text { of the } \\
\text { Floodplains }\end{array}$ \\
\hline \multirow{4}{*}{ Slope $(\%)$} & $\begin{array}{c}\text { Classes defined by System of Soil } \\
\text { classification }[47] \\
\text { Nearly level }(0 \%-2 \%)\end{array}$ & $64.3 \%$ & $59.1 \%$ & $9.9 \%$ & $78.6 \%$ & $85.7 \%$ & $17.6 \%$ \\
\hline & Very gentle to gentle slopes $(2.5 \%)$ & $14.3 \%$ & $30.6 \%$ & - & $10.7 \%$ & - & - \\
\hline & Gentle to moderate slopes $(5 \%-10 \%)$ & $7.1 \%$ & $10.3 \%$ & $10.1 \%$ & $3.6 \%$ & $7.2 \%$ & $5.9 \%$ \\
\hline & Strong to very strong slopes $(>10 \%)$ & $14.3 \%$ & - & $80.0 \%$ & $7.1 \%$ & $7.1 \%$ & $76.5 \%$ \\
\hline Micro-topography & $\begin{array}{l}\text { Succession of mounds and troughs } \\
(\mathrm{MT}) \text {; presence of bars (B); narrow } \\
\text { channel (NC); Gully; (G); Outcrop (O) }\end{array}$ & $\mathrm{MT}, \mathrm{B}, \mathrm{NC}$ & MT & G & $\mathrm{MT}, \mathrm{B}, \mathrm{NC}$ & MT & $\mathrm{G}, \mathrm{O}$ \\
\hline \multirow{4}{*}{ Drainage } & $\begin{array}{l}\text { Classes defined by System of Soil } \\
\text { classification [47] }\end{array}$ & $7.1 \%$ & $6.9 \%$ & $70.1 \%$ & $78.6 \%$ & $71.9 \%$ & $70.5 \%$ \\
\hline & Very good to good & & & & & & \\
\hline & Good to moderate & $21.4 \%$ & $20.5 \%$ & $40.0 \%$ & $14.2 \%$ & $14.3 \%$ & $17.5 \%$ \\
\hline & Bad to very bad & $71.4 \%$ & $72.6 \%$ & $9.9 \%$ & $7.2 \%$ & $14.1 \%$ & $12.0 \%$ \\
\hline \multirow{2}{*}{ Water table level } & L: less than 1 meter deep & L: $3.6 \%$ & L: $5.3 \%$ & L: - & $\mathrm{L}: 8.9 \%$ & L: $5.3 \%$ & L: $8.8 \%$ \\
\hline & G: greater than 1 meter deep & G: $96.4 \%$ & G: $94.7 \%$ & G: - & G: $91.1 \%$ & G: $94.7 \%$ & G: $91.2 \%$ \\
\hline Soil texture & $\begin{array}{l}\text { L: loam; LS: loamy sand; SL: sandy } \\
\text { loam; SiL: Silt loam; S: sand. } \\
\text { CS: coarse sand. FS: fine sand. System } \\
\text { of Soil classification [47] }\end{array}$ & L, LS, SL, FS & L, LS, SL, FS & $\begin{array}{c}\mathrm{S}, \mathrm{CS}, \mathrm{LS}, \\
\mathrm{SL}\end{array}$ & $\mathrm{L}, \mathrm{SL}, \mathrm{SL}$ & $\begin{array}{l}\mathrm{L}, \mathrm{LS}, \mathrm{SL}, \mathrm{FS} \\
\mathrm{S}\end{array}$ & $\begin{array}{l}\text { S, CS, LS, } \\
\text { SL }\end{array}$ \\
\hline
\end{tabular}


Table 2. Cont.

\begin{tabular}{|c|c|c|c|c|c|c|c|}
\hline \multicolumn{2}{|r|}{ Biophysical variables } & \multicolumn{3}{|c|}{ MAS Sector } & \multicolumn{3}{|c|}{ STF Sector } \\
\hline Variable & Variable Description & $\begin{array}{c}\text { Flood } \\
\text { Recurrence } \\
(\mathbf{0}-20 \text { years })\end{array}$ & $\begin{array}{c}\text { Flood } \\
\text { Recurrence } \\
(\mathbf{2 0 - 1 0 0} \text { years })\end{array}$ & $\begin{array}{c}\text { Outside } \\
\text { of the } \\
\text { Floodplains }\end{array}$ & $\begin{array}{c}\text { Flood } \\
\text { Recurrence } \\
(0-20 \\
\text { years })\end{array}$ & $\begin{array}{c}\text { Flood } \\
\text { Recurrence } \\
(\mathbf{2 0}-\mathbf{1 0 0} \text { years })\end{array}$ & $\begin{array}{c}\text { Outside } \\
\text { of the } \\
\text { Floodplains }\end{array}$ \\
\hline \multirow{3}{*}{ Particle size $(\%)$} & Clay $(>5 \%)$ & $4.3 \%$ & $5.2 \%$ & $5.3 \%$ & $2.5 \%$ & $2.6 \%$ & $2.5 \%$ \\
\hline & Sand $(>50 \%)$ & $32.6 \%$ & $27.7 \%$ & $32.4 \%$ & $46.8 \%$ & $46.8 \%$ & $51.4 \%$ \\
\hline & Silt $(>60 \%)$ & $63.1 \%$ & $67.1 \%$ & $62.3 \%$ & $50.7 \%$ & $50.6 \%$ & $46.1 \%$ \\
\hline \multirow{3}{*}{ Soil pH $\left(\mathrm{CaCl}_{2}\right)$} & $3.5-4.5$ & $35.7 \%$ & $57.4 \%$ & $79.9 \%$ & $21.4 \%$ & $57.1 \%$ & $100 \%$ \\
\hline & $4.5-5.5$ & $57.2 \%$ & $42.6 \%$ & $20.1 \%$ & $39.3 \%$ & $35.8 \%$ & - \\
\hline & $5.5-6.5$ & $7.1 \%$ & - & - & $39.3 \%$ & $7.1 \%$ & - \\
\hline \multirow{3}{*}{$\begin{array}{l}\text { Soil biomass } \\
\quad \text { (litter) }\end{array}$} & $0-1 \mathrm{~cm}$ & $66.7 \%$ & $40.6 \%$ & $19.9 \%$ & $82.1 \%$ & $36.7 \%$ & $17.6 \%$ \\
\hline & $1-3.5 \mathrm{~cm}$ & $27.1 \%$ & $50.0 \%$ & $30.1 \%$ & $14.3 \%$ & $63.3 \%$ & $23.5 \%$ \\
\hline & $>3.5 \mathrm{~cm}$ & $6.2 \%$ & $9.4 \%$ & $50.0 \%$ & $3.6 \%$ & - & $58.9 \%$ \\
\hline $\begin{array}{c}\text { Deciduous } v s \\
\text { coniferous }\end{array}$ & $\begin{array}{c}\text { Proportion of deciduous trees in } \\
\text { quadrat }\left(200 \mathrm{~m}^{2}\right) \text { by zones and sectors }\end{array}$ & $78.6 \%$ & $79.6 \%$ & $70.1 \%$ & $90.2 \%$ & $80.4 \%$ & $27.8 \%$ \\
\hline Density of trees & $\begin{array}{l}\text { Average density of trees in quadrat } \\
\left(200 \mathrm{~m}^{2}\right) \text { by zones and sectors }\end{array}$ & 24.1 & 30.8 & 32.5 & 23.1 & 30.8 & 32.5 \\
\hline
\end{tabular}

${ }^{\text {a }}$ See also the reference [48] for more details in soil properties. 
The mean annual discharge of the section of the Saint-François River (the longest time series) located in the study area shows variations over the last decades (1950-2010), with a significant increase in river flow discharge, especially after the 1970s, preceded by a decrease in flow before 1960 [36,49]. The years 1982, 1994 and 1996 have the highest discharge and there is a significant increase in the mean annual discharge in the last few decades, especially from 1970-1998, with a downward trend after 2000 (Figure 2). The variations in the peak discharge are generally very similar to the variations in the mean annual discharge. The years 1982, 1990 and 1996, which are characterized by peak discharge, are thus easily located on the mean annual discharge graph. The decrease in discharge recorded around 1960 and 1964 is also clearly identified [36,49]. Furthermore, the years marked by high discharge are generally years with considerable rainfall. The peak discharge generally corresponds to the major floods (e.g., 1982, 1996) recorded in the watershed basin (Figure 2). The increased flooding in recent decades has impacts on soil forming processes (e.g., rejuvenation of soil), and consequently on tree communities of riparian zones [35,37].

After 2010, no major floods were recorded in the Saint-François river basin, except for the flood on August 30, 2011 related to Hurricane Irene that originated from the U.S. eastern seaboard. This major hurricane caused torrential rains and heavy winds, resulting in major damage and flooding in several rivers in southern Québec. The peak discharge for the Saint-François River recorded during the August 2011 flood was $1227 \mathrm{~m}^{3} \cdot \mathrm{s}^{-1}$ (gauging station no. 030208), which was below the values recorded in 1982 $\left(2420 \mathrm{~m}^{3} \cdot \mathrm{s}^{-1}\right)$ and $1996\left(2719 \mathrm{~m}^{3} \cdot \mathrm{s}^{-1}\right)$ corresponding to major floods in the Saint-François river basin.

Lastly, based on the hydromorphological data available on the river morphology for the two rivers under study [42,43], the Saint-François and Massawippi rivers have an average depth of 4-8 meters and 1.5-4 meter, respectively. The rivers have a rather straight course delimited by rocky outcrops and a few meandering areas bordered by floodplains. The rivers have a rocky substratum primarily made up of igneous or metamorphic rocks that are exposed in several areas along the river corridor. These outcrops are more visible in the upstream sections of the Massawippi river and are mainly found in the middle course of the Saint-François River (between Sherbrooke and Drummondville). In agricultural or wooded areas, the outcrops are less visible and are often covered with fine sediment (mainly of fluvial origin) that can easily reach 2-3 meters in thickness $[36,40]$. This fine sediment (e.g., silt, sandy loam or fine sand) can be remobilized and transported further downstream during floods. 


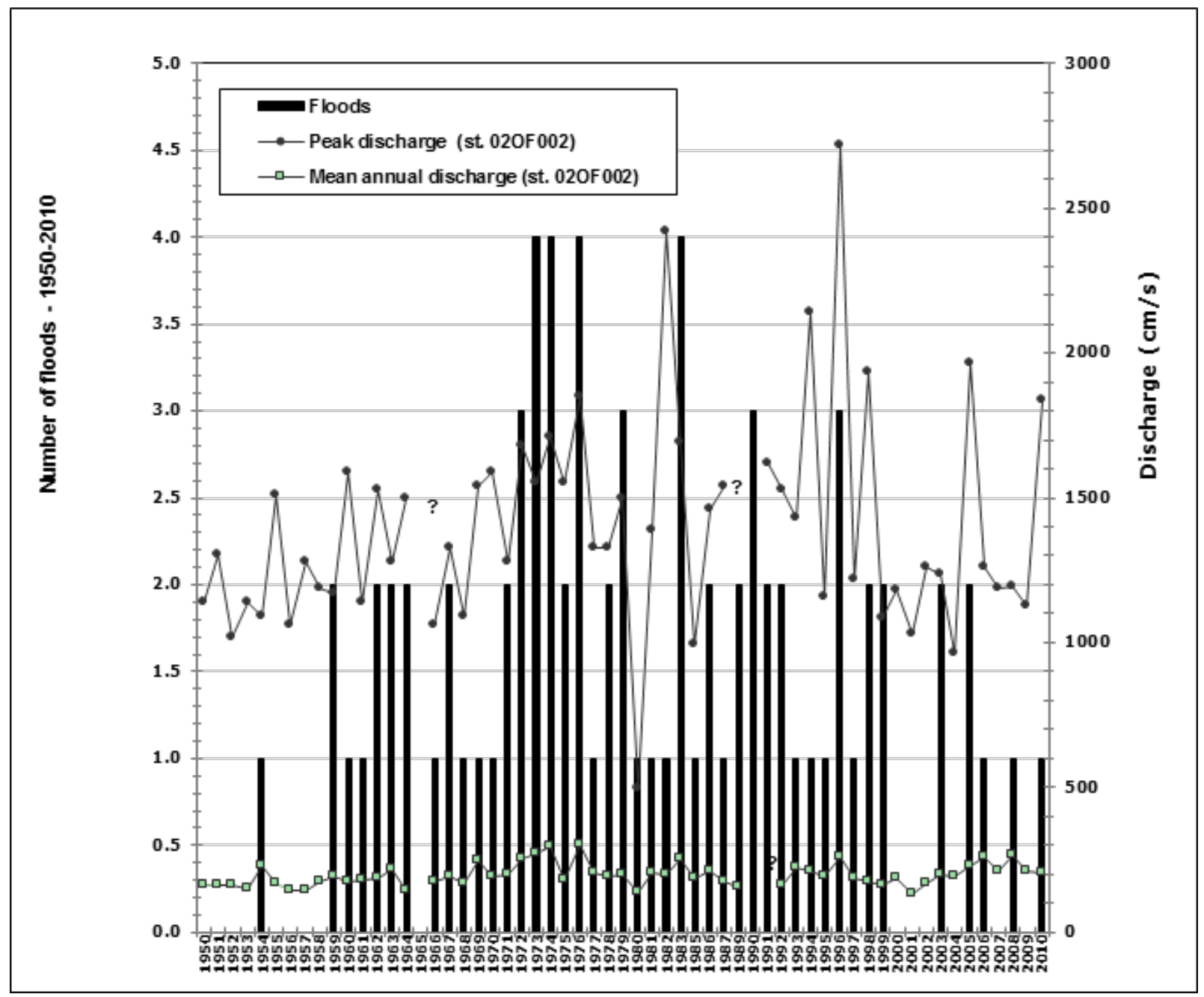

Figure 2. Flood time series for the period between 1950 and 2010 for the Saint-François River basin based on flow records from gauging station (02OF002) at Drummondville.

\subsection{Field Sampling}

The sampling sites are located along the riverbanks of the Massawippi and Saint-François rivers, in the woodland areas. The Massawippi River floodplains are made up of large flat surfaces (20-50 m on average) mainly found in the middle course of the river and made up of fine sediment (loam and loamy sand). The area is dominated by stands of ash species (Fraxinus pennsylvanica and F. nigra) with a few other hardwood and softwood species. In the middle course of the Saint-François River, the floodplains expand mainly around Richmond and form large subhorizontal areas that sometimes extend over more than 150 meters. The floodplains are made up of low terraces consisting of fine materials (fine sand, loam or sandy loam). Ash (F. pennsylvanica and F. nigra) is the dominant tree species in the floodplains along with species such as Acer saccharum, Prunus serotina, Abies balsamea and Acer negundo in the more open areas.

Sampling was done from June-August 2011 and 2012, and vegetation data were collected in quadrats with a surface area of $10 \mathrm{~m} \times 20 \mathrm{~m}$. The sampling sites are located along a longitudinal gradient (transect perpendicular to the bank). The majority of the sampling sites (66 quadrats) are found in the floodplains zones and the rest of the sites (48 quadrats) are located outside the floodplains (Figures 3 and 4). The quadrats served as a reference unit for all the sampling sites found across the different flood recurrence zones 
(intervals of 0-20 years (Frequent flood zone/FFz) and 20-100 years (Moderate flood zone/MFz), and outside the floodplains (no-flood zone/NFz), for a total of 94 quadrats; i.e., 30 quadrats (STF sector) and 14 quadrats (MAS sector) in frequent flood zones (FFz); 15 (STF sector) and 7 (MAS sector) quadrats in moderate flood zones; 18 (STF sector) and 10 (MAS sector) quadrats outside the floodplains). Systematic surveys of the tree stratum were done for each stand to identify the species and each tree was measured at breast height (DBH: $1.3 \mathrm{~m}$ high) to determine its diameter. The structure of the tree populations was also calculated based on the number of stems for a given species per surface unit, for a total of 2633 tree stems measured and identified in all the tree stands. Trees more than a one meter in height were recorded in the total number of trees in each quadrat. Various biophysical variables were also measured such as slope and microtopography, drainage, soil texture and canopy density, while taking into account the various flood recurrence zones as well as the extent of the visible disruption.

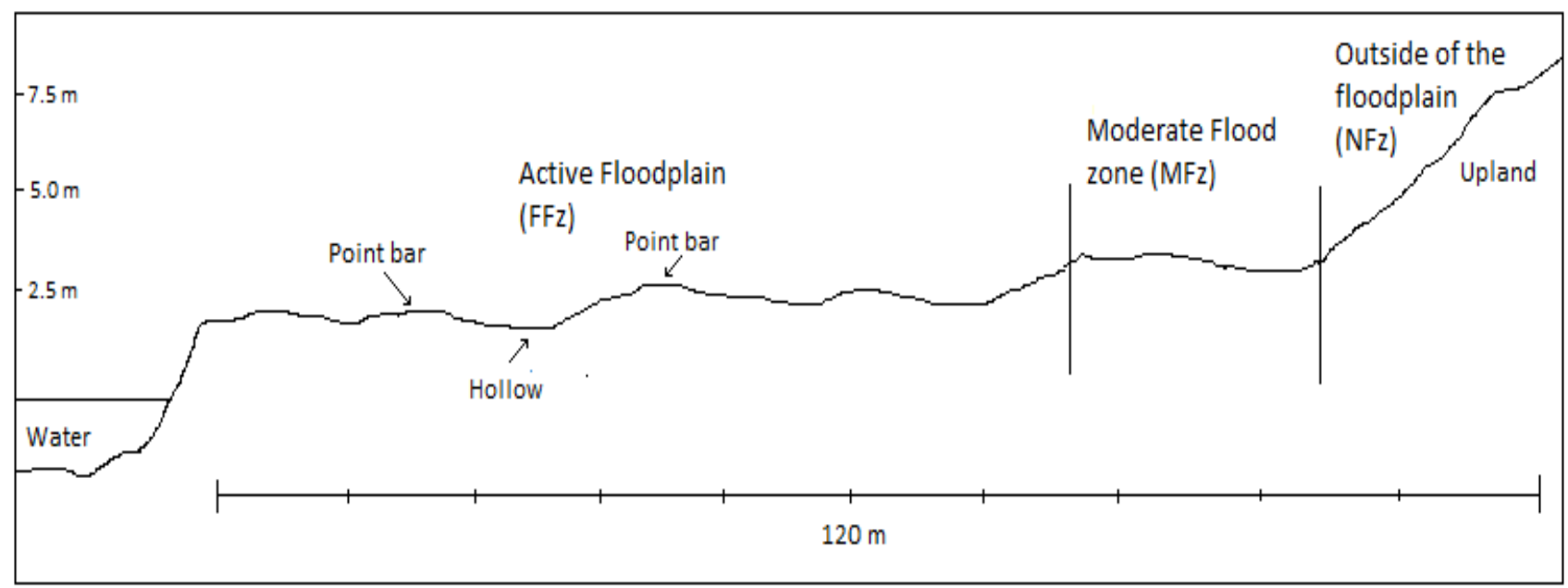

Figure 3. Topographic profile showing the different flood zones (FFz and $\mathrm{MFz}$ ) and zones outside the floodplain along a longitudinal gradient (perpendicular to the bank). Floodplains are relatively flat with a succession of mounds and troughs due to erosion and sedimentation. 

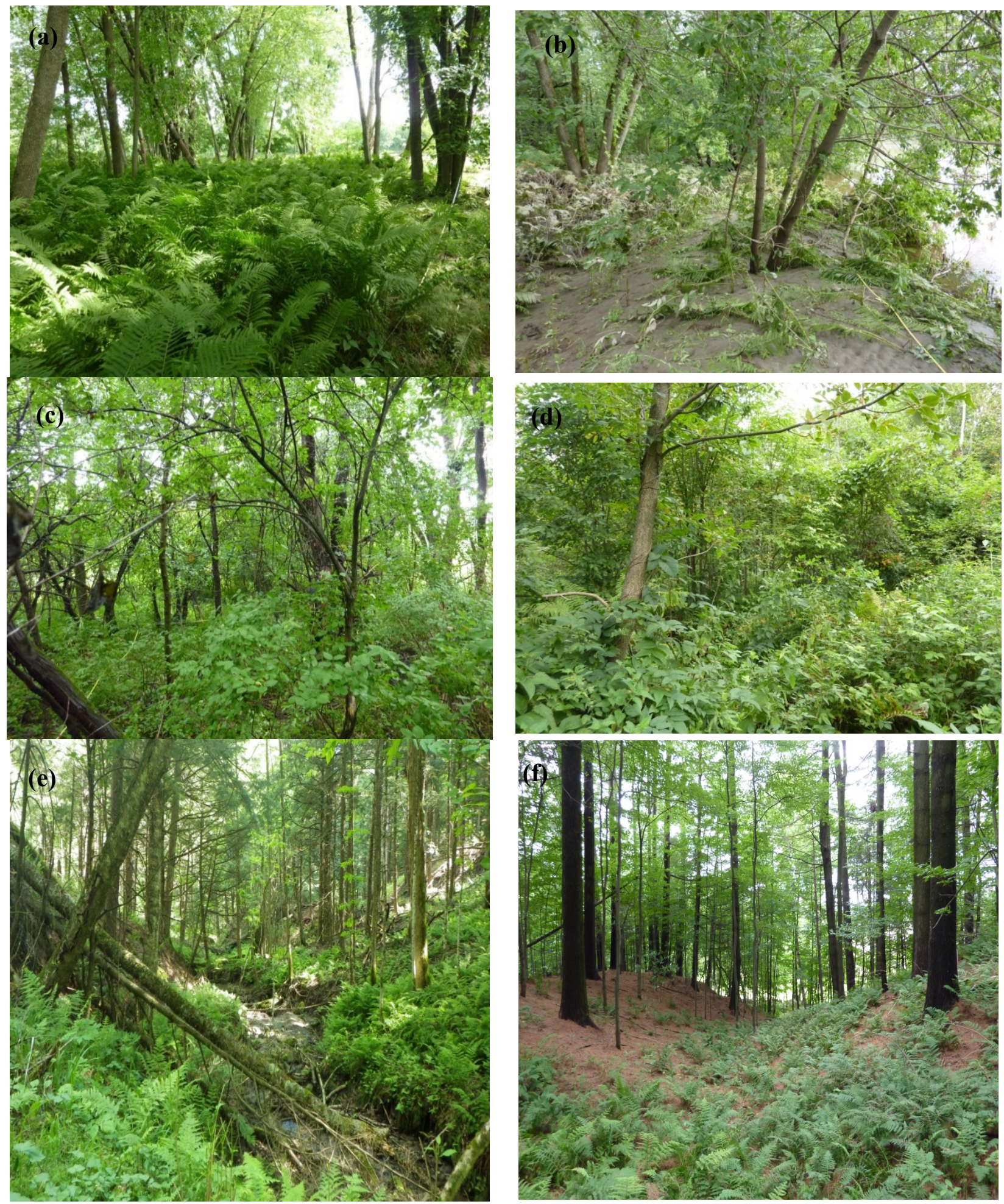

Figure 4. Photographs of tree stands in different flood risk zones and in no-flood zones in the two sectors (MAS and STF); (a) Typical tree stand on active floodplain (Richmond sector). In the zone with frequent flood recurrence (interval of 0-20 years), the old trees are often dominant and the stands are characterized by a very low regeneration rate; (b) Riparian trees affected by summer flood (August 30, 2011 (Richmond sector); (c) Young forests located in intermediate flood zones (interval of 20-100 years) (MAS sector); (d) Typical tree stand in intermediate zone (STF sector); (e) Tree stands in uplands located along the Massawippi and (f) Saint-François rivers (Windsor sector). 


\subsection{Statistical Analysis}

For the initial part of the data processing, Shapiro-Wilk tests were conducted to check the distribution and normality of the raw data. Logarithmic transformation was applied (tree stem data) in order to obtain a symmetrical distribution curve. Normal data distribution is a condition required for the use of different statistical tests, including parametric (e.g., Student and Fisher tests) and non-parametric tests (e.g., Mann-Whitney). The data based on the flood recurrence zones were compared using Student or Mann-Whitney-Wilcoxon tests. Statistical analysis were done using the R software [50], including ordinations (Principal Coordinates Analysis), parametric and non-parametric statistical tests, diversity analyses, and similarity indices (e.g., Shannon and Sørensen index), as well as the Principal Coordinates Analysis (PCoA). This last method is used to explore and view data dissimilarities. This analysis was applied using a similarity matrix (e.g., Sørensen’s coefficient) and a location was assigned for each item (= distance matrix) in a low-dimensional space. The calculations took into account the presence/absence of tree species, their abundance, and the degree of similarity between the quadrats. The species richness analysis was used to determine the number of species found in a given area (e.g., quadrat). However, it could not be used to determine the uniformity of these species in this area, which is why the Shannon index was used. The Sørensen index is a similarity analysis used to detect similarities in species composition between the quadrats. These different methods are useful for properly assessing the main characteristics of the forest cover. Lastly, a significance level of $95 \%(0.05)$ was determined for all the statistical tests.

Alpha and beta diversity was used to determine the species richness for all the tree stands. Alpha diversity was used to determine species diversity on a local scale. The Shannon index was used for this purpose.

This index is calculated as follows:

$$
H^{\prime}=-\sum_{i=1}^{s} p_{i} \log _{2} p_{i}
$$

$\mathrm{H}^{\prime}$ represents the biodiversity index on its own. $p_{\mathrm{i}}$ is calculated as follows:

$$
p_{i}=n_{i} / N
$$

where $N$ is the total number of individuals and $n_{i}$ is the number of each tree species present for each quadrat.

However, alpha diversity cannot determine the differences between two quadrats, whereas beta diversity (diversity- $\beta$ ) is more appropriate for determining inter-site biodiversity. This allows a comparison to be done of the number of taxa (e.g., tree species) unique to each of the quadrats inventoried. For the purposes of the present study, the Sørensen index was used, which is calculated as follows:

$$
Q S=\frac{2 C}{A+B}=\frac{2|A \cap B|}{|A|+|B|}
$$

where $Q S$ represents the calculation index, $A$ and $B$ the number of species in sample $A$ and sample $B$, and $C$ the number of species shared between the two samples. The calculation provides an index ranging from $1-0$. The value of " 1 " corresponds to two quadrats made up of the same tree species, and " 0 " means two completely different quadrats. In other words, the closer the values to 1 , the more the quadrats being compared share the same tree species. 


\section{Results}

\subsection{Species Richness}

A comparison of the number of species and the diversity of the quadrats reveals marked differences between the flood recurrence zones (FFz and $\mathrm{MFz}$ ) and the no-flood zones (NFz). The Mann-Whitney-Wilcoxon tests revealed significantly higher species richness in the intermediate zones (20-100 years) compared to the high flood risk zones (interval of 0-20 years) and the no-flood zones (Figure 5). The $p$-values obtained for the various zones by comparing them two by two are $p<0.000$ for FFz and MFz, $p=0.0117$ for FFz, and NFz, and $p=0.1830$ for MFz and NFz. There is a higher number of tree species in the intermediate zones, which act as a transition between the high flood risk zones and no-flood zones. Species such as Fraxinus nigra Marsh., Abies balsamea (L.) Miller, and Carpinus caroliniana Walt are the most abundant trees in the intermediate zones (see also Appendix). There is a statistically significant difference $(p<0.001)$ in terms of species richness between the high flood risk zones and the no-flood zones.

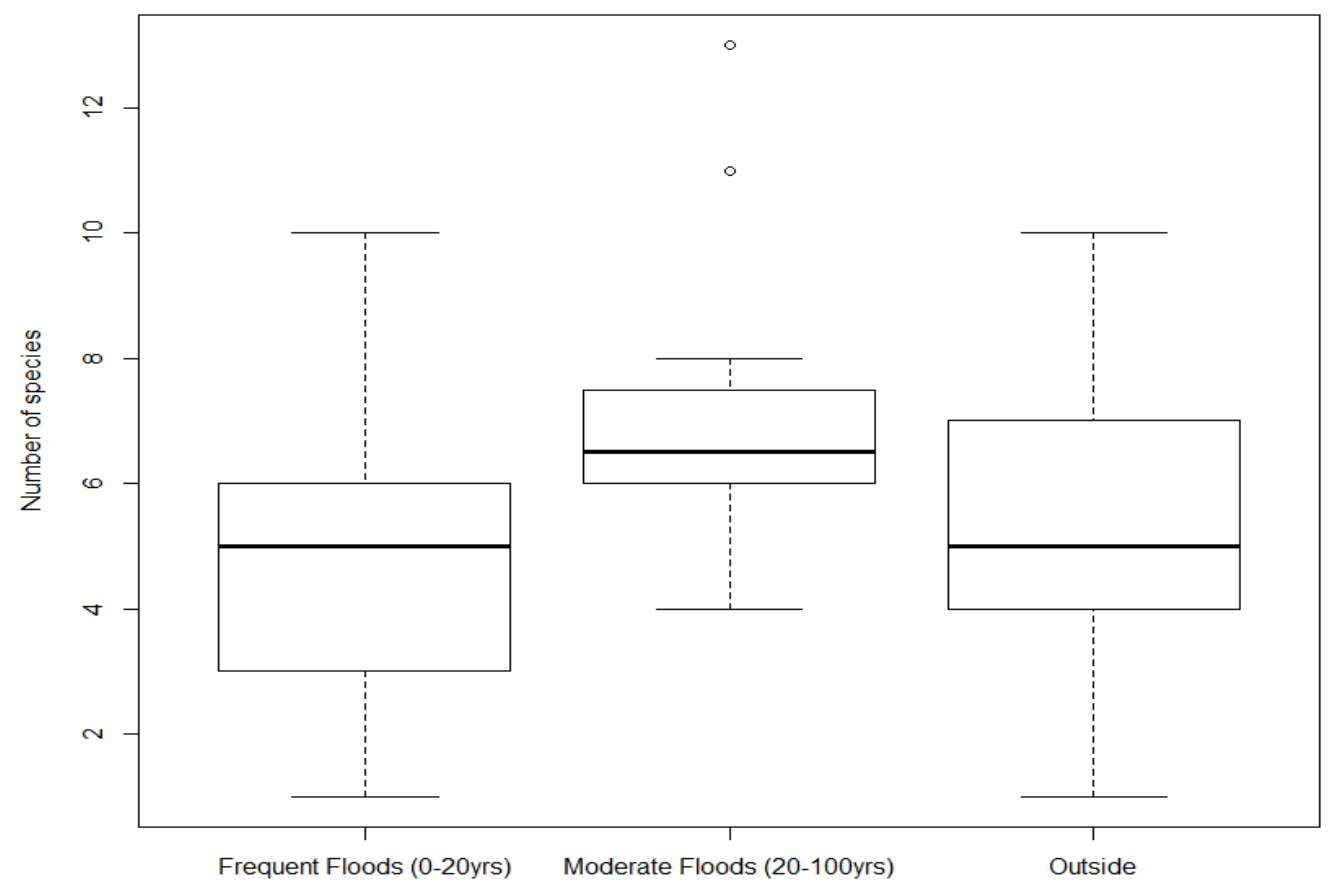

Figure 5. Graph of species richness following the three different zones (Flood recurrence interval of 0-20 years; Flood recurrence interval of 20-100 years; Outside the floodplains).

\subsection{Biodiversity Index and Beta Diversity}

The Shannon index enabled the heterogeneity of the various quadrats to be determined and revealed marked differences among the various zones being studied. The intermediate zones seem to be clearly more heterogeneous than the other two zones (Figure 6). Heterogeneity in the intermediate zone (MFz) results in greater tree species diversity compared to the quadrats more affected by flooding, for instance. The statistical test revealed significantly higher heterogeneity for the intermediate zones compared to 
the other two zones (FFz: $p<0.001$; NFz: $p=0.001$ ). In the latter cases, the resulting indices are similar and are not significantly different from a statistical standpoint.

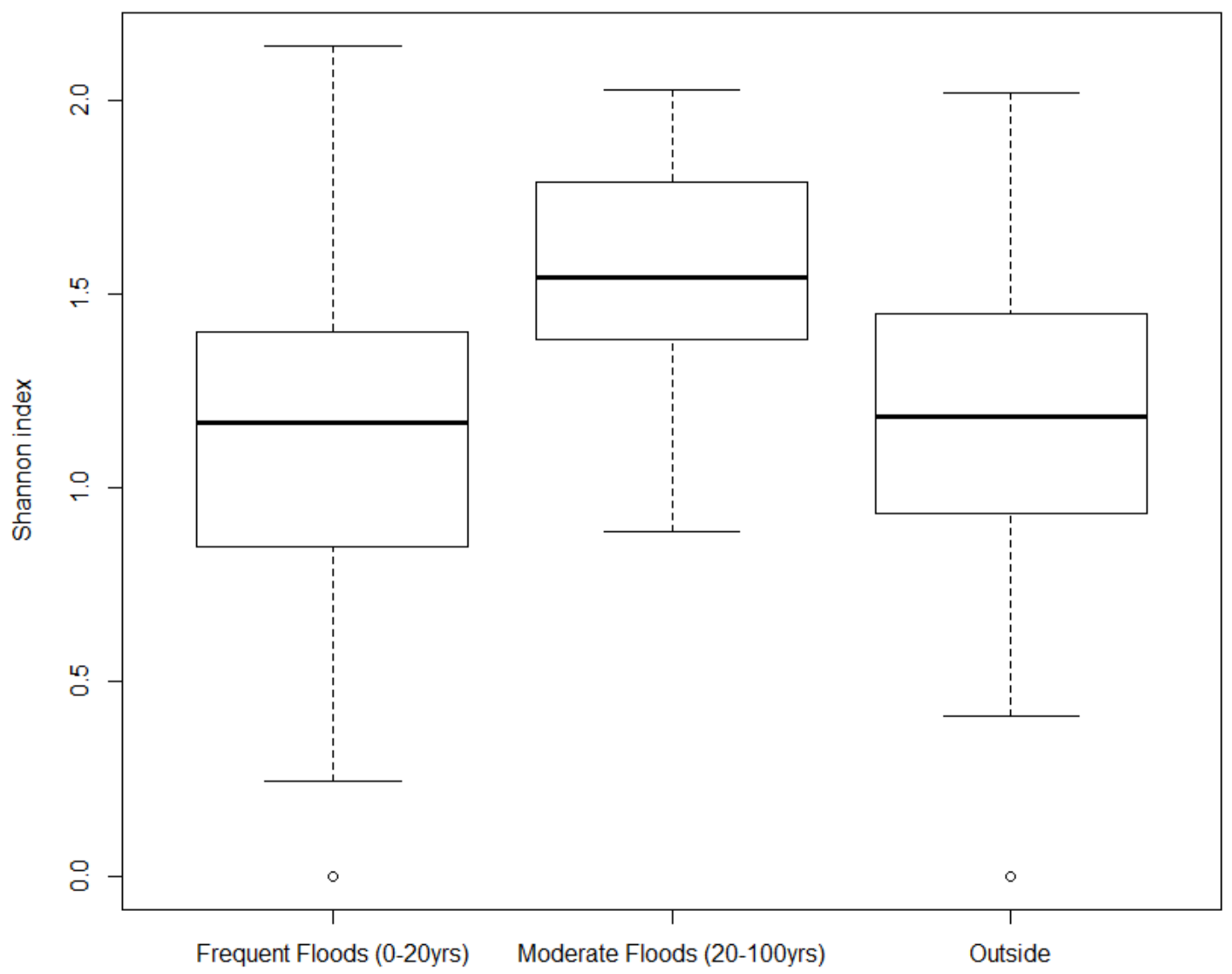

Figure 6. Graph of Shannon index of tree diversity based on the three different zones (Flood recurrence interval of 0-20 years; Flood recurrence interval of 20-100 yrs; Outside the floodplains).

The Principal Coordinate Analysis (PCoA) performed on the tree species (total of 94 quadrats) reveals marked differences regarding species distribution and composition. The PCoA are based on the similarity matrix (Sørensen coefficient), which shows specific groupings based on the various zones under study. The high flood risk zones clearly stand out from the other two zones. The quadrats located in the high flood risk zones are grouped mainly to the right of Axis 1 (Figure 7). The first axis primarily separates the quadrats affected by frequent flooding from those outside the floodplains. This represents a clear differentiation in the composition of the inter-site forest stands (quadrats). This eccentric position along the axis reveals the effects of environmental factors (e.g., edaphic conditions, successive floods, drainage and slope) (Table 2), which probably play a specific role in the distribution of the species tree (e.g., species with a tolerance and intolerance to humid conditions). The no-flood zones are mainly found to the left of Axis 1 and form a central core around Axis 2, while the intermediate zones are found along Axis 2, thus sharing traits with regard to tree species composition with the other two zones, but with a higher richness of tree species. 


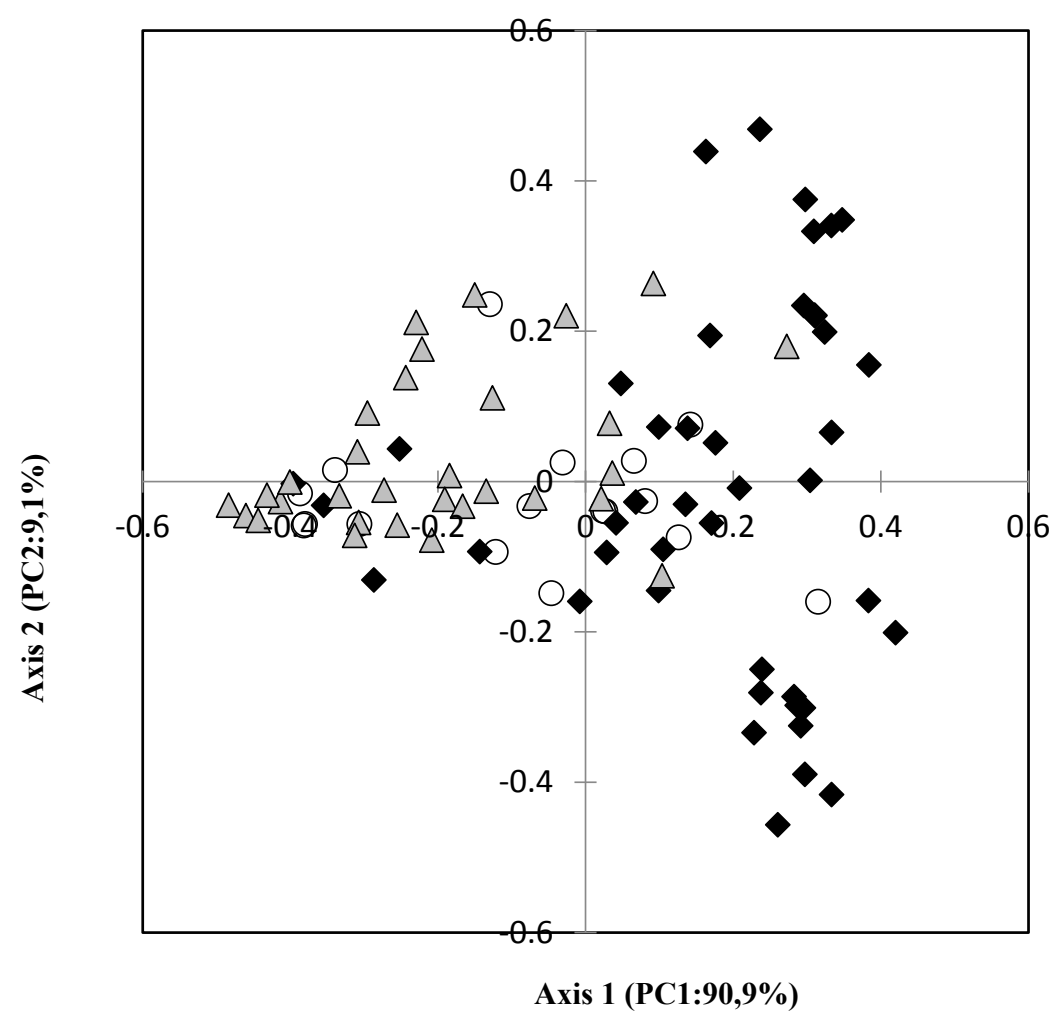

Figure 7. Principal Coordinates Analysis (PCoA) of the tree specimens based on Sørensen's similarity matrix. The zones of high flood recurrence interval ( $0-20$ years) are represented by black diamonds; zones of intermediate flood recurrence interval (20-100 years) by white circles and zones located outside the floodplains by grey triangles.

\subsection{Distribution of Tree Species}

Figure 8 shows the composition and distribution of the tree species grouped by flood zone (FFz and $\mathrm{MFz}$ ) and no-flood zone (NFz). The data include both study areas (MAS and STF sectors) for each tree species. Although several species are common to all the quadrats, there are marked differences between the zones, in particular with respect of the number of species inventoried. For instance, Fraxinus pennsylvanica (FRPE) is the dominant species in the high-flood zones (FFz), while Fraxinus nigra (FRNI) is better represented in the intermediate flood zones (MFz). Outside the floodplains, Abies balsamea (ABBA) is the dominant species, followed by Acer rubrum (ACRU) and Tsuga canadensis (TSCA). Figure 9 also shows the distribution of the main tree species grouped by flood zone (FFz and MFz) and no-flood zone (NFz), and based on the two river sectors (MAS and STF sectors). Species such as Abies balsamea (ABBA), Acer saccharum (ACSA) and Tsuga canadensis (TSCA) are widely represented in the no-flood zones; however, species of ash such as Fraxinus pennsylvanica (FRPE) and Fraxinus nigra (FRNI) prefer wetter areas such as the high flood risk zones. Note that Acer rubrum (ACRU) is more abundant in the no-flood zones, although it has fairly good coverage in the flood zones (MFz). Among all the tree species inventoried, only box elder (Acer negundo L.) constitutes an exotic species. Native to the American West, box elder is significantly more abundant $(p=0.024)$ in high-flood zones than in intermediate-flood and no-flood zones, where it is virtually absent. 


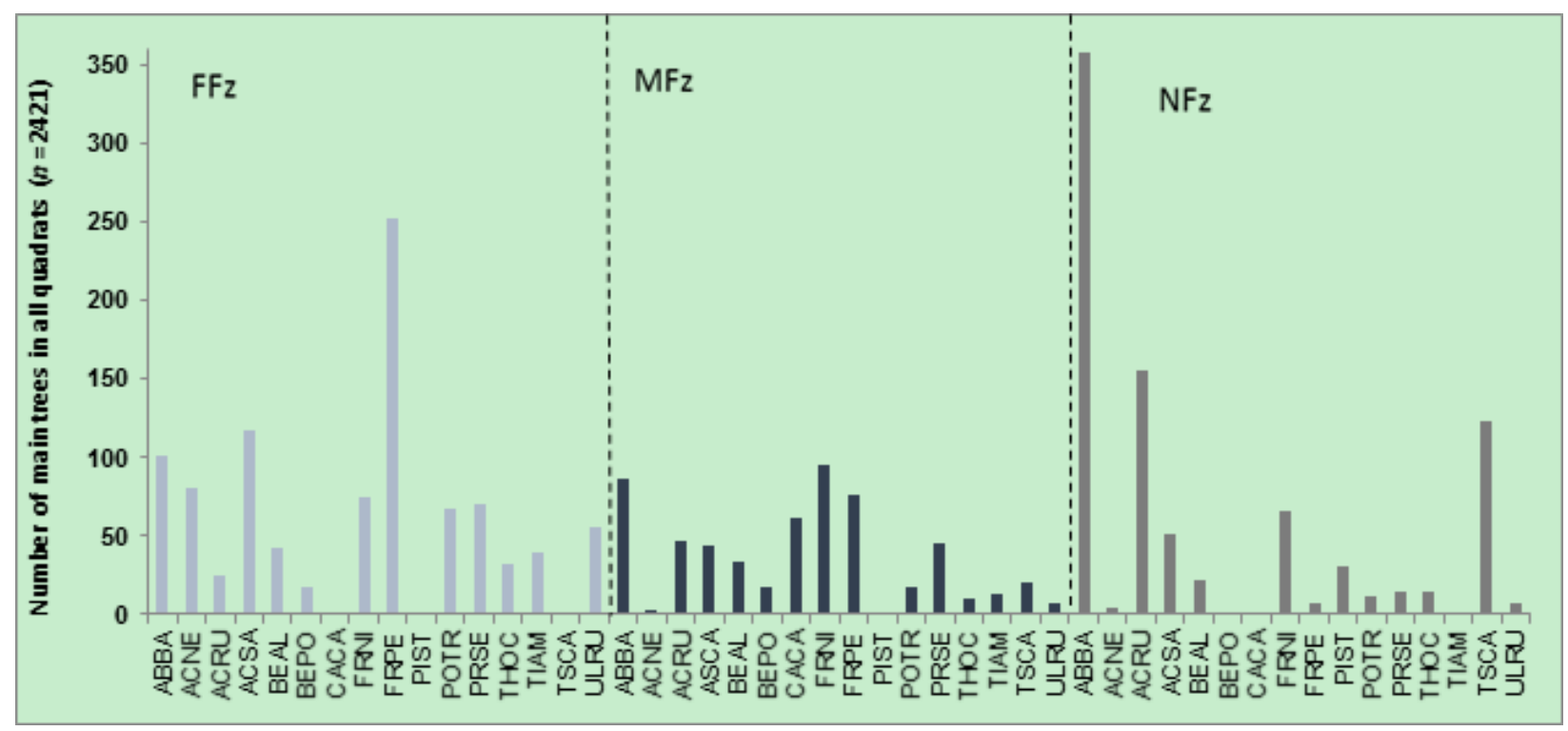

Figure 8. Composition and distribution of tree specimens in different study areas. The zones with a high flood recurrence interval (FFz: 0-20 yrs) are represented in blue color; zones with an intermediate flood recurrence interval (MFz: 20-100 yrs) are in black color, and grey color for no-flood zones (NFz) (Note: Only tree species with over 25 individuals are shown in the graph). (Legend: ABBA: Abies balsamea; ACNE: Acer negundo; ACRU: Acer rubrum; ACSA: Acer saccharum; BEAL: Betula alleghaniensis; BEPO: Betula populifolia; CACA: Carpinus caroliniana; FRNI: Fraxinus nigra; FRPE: Fraxinus pennsylvanica; PIST: Pinus strobus; POTR: Populus tremuloides; PRSE: Prunus serotina; THOC: Thuya occidentalis; TIAM: Tilia americana; TSCA: Tsuga canadensis; URLU: Ulmus rubra.

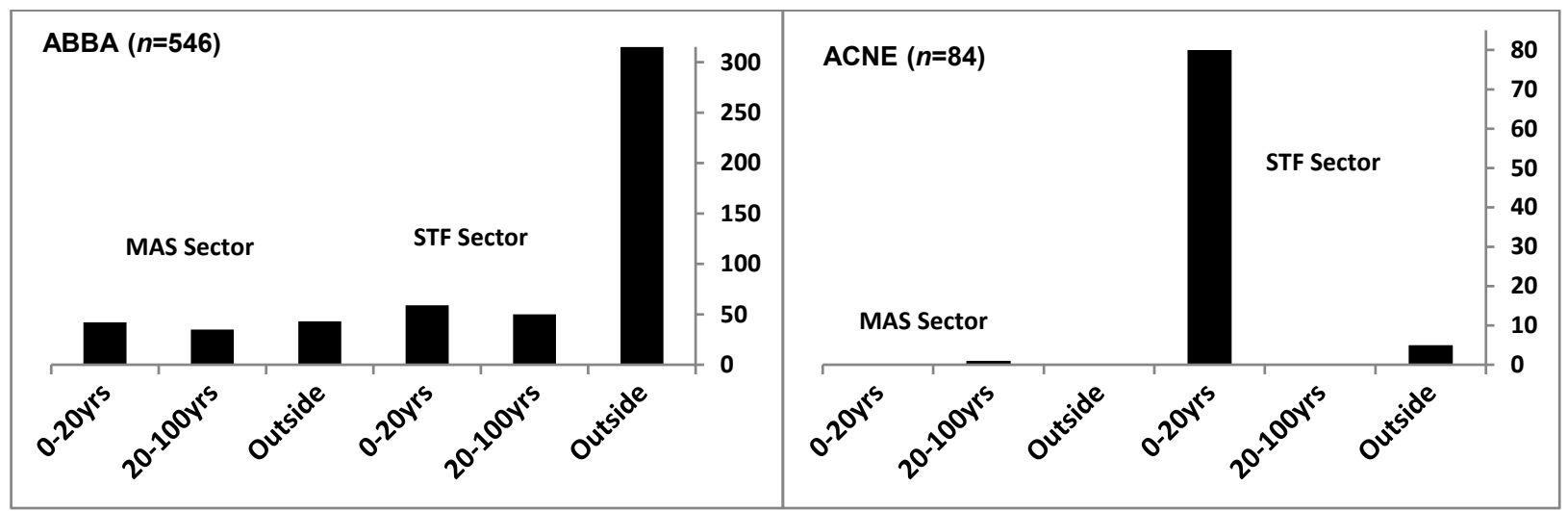

Figure 9. Cont. 

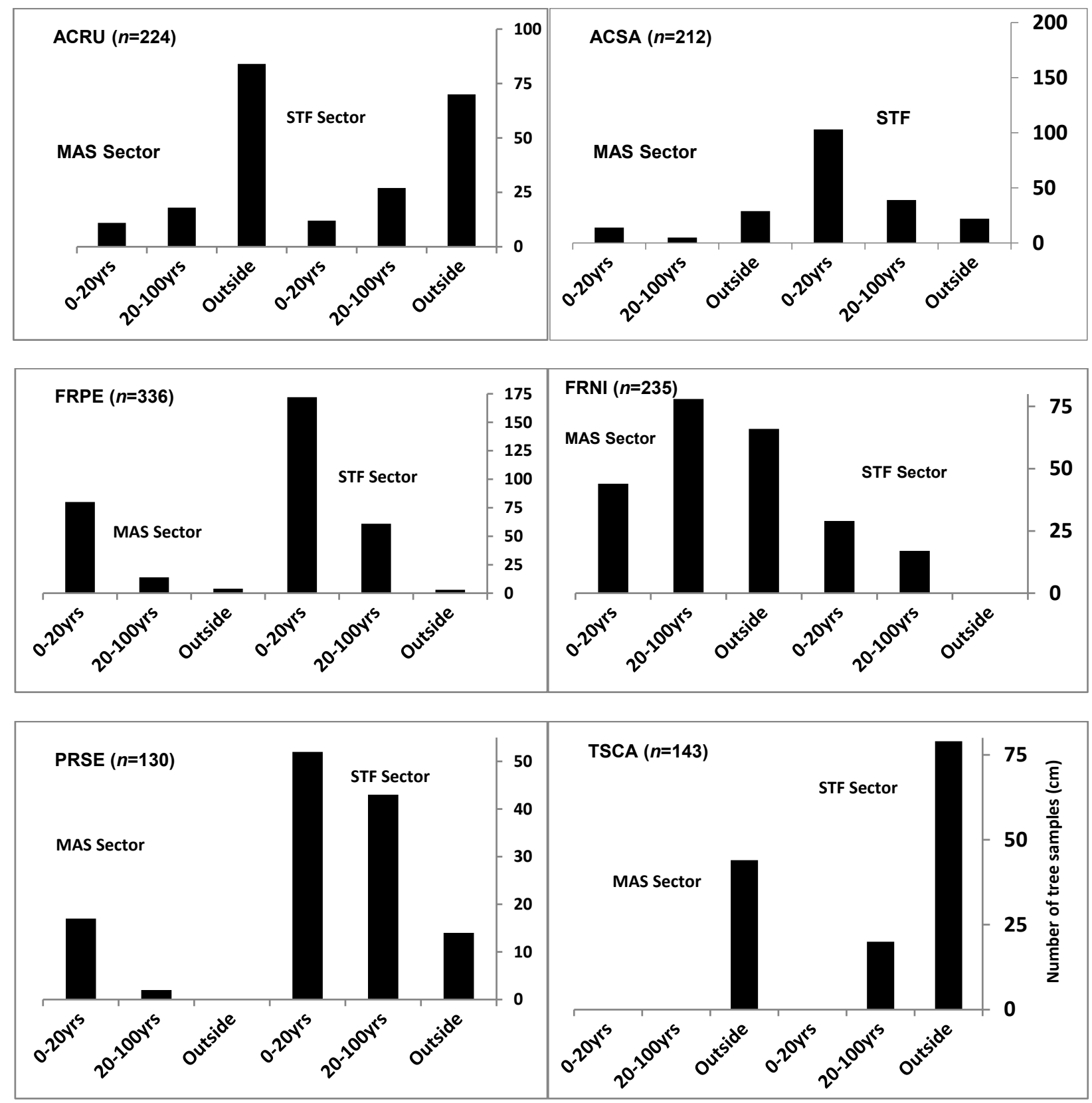

Figure 9. Distribution of main tree species in different flood zones (intervals of 0-20 yrs and 20-100 yrs) and no-flood zones, and by sector (Massawippi (MAS) and Saint-François (STF) rivers). (Legend: ABBA: Abies balsamea; ACNE: Acer negundo; ACRU: Acer rubrum; ACSA: Acer saccharum; FRPE: Fraxinus pennsylvanica; FRNI: Fraxinus nigra; PRSE: Prunus serotina; TSCA: Tsuga canadensis).

Table 3 shows the different characteristics of the composition and structure of the quadrats, along with their relative occurrence for all the tree stands and the number of tree stems based on the diameter categories $(<10 \mathrm{~cm}, 20-30 \mathrm{~cm}$, and $>30 \mathrm{~cm} \mathrm{DBH})$. Fraxinus pennsylvanica is the most common species in the FFz zone (total of 252) with a relatively high density (9.6\%), whereas the MFz zone is mainly characterized by Fraxinus nigra (total of 95) and Abies balsamea (total of 87), which are found in greater number but at a much lower density (3.6\% and 3.3\%, respectively) for all the quadrats ( $n=2633$ tree species). In the NFz zones, Abies balsamea (total of 358), Acer rubrum (total of 161) and 
Tsuga canadensis (total of 123) are the most representative of these quadrats and have a relatively high or moderate density $(13.6 \%, 6.1 \%$ and $4.7 \%$, respectively).

Regarding the diameter categories (Table 3), it can be noted that most of the quadrats are made up of small-diameter trees $(<10 \mathrm{~cm} \mathrm{DBH})$, which indicates young stands, especially for the high-flood zones $(\mathrm{FFz})$, which are characterized by a higher number of young individuals, i.e., over $63 \%$ of the trees inventoried in the zone. This is the case for species such as Populus tremuloides, Abies balsamea and Acer saccharum, which are characterized by a strong representation of small-diameter trees ( $<10 \mathrm{~cm} \mathrm{DBH}$ ), equivalent to $89 \%, 87 \%$ and $79 \%$, respectively. For the other two zones ( $\mathrm{MFz}$ and NFz), the small-diameter trees respectively represent $55 \%$ and $54 \%$ of the total trees inventoried. Large-diameter trees $(>30 \mathrm{~cm} \mathrm{DBH})$ are almost evenly distributed in each zone (between $4.6 \%$ and 5.8\%). Note that Tsuga canadensis and especially Pinus strobus are the species with the largest number of trees with diameters greater than $30 \mathrm{~cm}$, and these two species are only found outside the floodplains. Lastly, trees with a very large diameter (i.e., $>60 \mathrm{~cm} \mathrm{DBH}$ ) are rather rare and account for less than $1 \%$ of the total trees inventoried.

\section{Discussion}

\subsection{Composition and Species Diversity}

With respect to species composition and diversity, the data show a slightly higher number of tree species in the intermediate flood risk zones (MFz). Favorable edaphic and hydrological conditions (i.e., lower flood frequency, moderate moisture, and low to moderate slope) may account for the larger diversity of tree species in the intermediate zone [29-31]. It is also likely that this transition zone benefits from the effects of the neighboring zones, each with its own different tree species. These transition zones in a riparian environment are in fact often considered as more diversified areas as a result of their intermediate position [35,51-53]. For instance, it is reported that the trees located a little further away from the channel are less vulnerable to the intensity and frequency of flood disturbances (e.g., erosion vs. sedimentation processes) [30-32].

Conversely, the tree or shrub species found in the floodplains frequently affected by floods or subjected to variable hydrological regimes continue to be more vulnerable. For instance, some studies [54,55-57] show that the seed dispersal and seedling establishment of certain tree species could be more or less synchronous with the hydrological regime, which results in different establishment modes based on the species (e.g., after a peak flow). Certain riparian tree species have in fact developed establishment strategies (e.g., timing of seed development) to counter certain adverse effects associated with the river system, in particular greater seed dispersal after major floods associated with snowmelt timing, or after annual peak river flows, for instance [54,55]. However, the successful establishment of seedlings is not necessarily linked to the vitality and survival of these new plants, especially if the seedlings are affected by heavy floods. 
Table 3. Characteristics of quadrats in the two flood zones (FFz and MFz) and outside the floodplains (NFz) along the Massawippi and Saint-François rivers in southern Québec, Canada.

\begin{tabular}{|c|c|c|c|c|c|c|c|c|c|c|c|c|c|c|c|c|c|c|}
\hline \multirow[t]{2}{*}{ Dominant Tree Species } & \multicolumn{3}{|c|}{ Total Tree Stems } & \multicolumn{3}{|c|}{$\begin{array}{c}\text { Relative Density a } \\
(\%)\end{array}$} & \multicolumn{3}{|c|}{ Tree Diameter min-max (cm) } & \multicolumn{3}{|c|}{$\begin{array}{l}\text { Tree Diameter } \\
\quad(<10 \mathrm{~cm})\end{array}$} & \multicolumn{3}{|c|}{$\begin{array}{c}\text { Tree Diameter } \\
(10-30 \mathrm{~cm})\end{array}$} & \multicolumn{3}{|c|}{$\begin{array}{l}\text { Tree Diameter } \\
\quad(>30 \mathrm{~cm})\end{array}$} \\
\hline & FFz & MFz & NFz & $\mathbf{F F z}$ & MFz & NFz & FFz & MFz & $\mathbf{N F z}$ & FFz & MFz & NFz & FFz & MFz & $\mathbf{N F z}$ & $\mathbf{F F z}$ & MFz & NFz \\
\hline Abies balsamea & 101 & 87 & 358 & 3.8 & 3.3 & 13.6 & $1.4-37.2$ & $0.5-39.8$ & $0.5-30.5$ & 87 & 46 & 242 & 11 & 39 & 115 & 3 & 2 & 1 \\
\hline Acer negundo & 81 & 3 & - & 3.1 & 0.1 & - & $1.2-54.0$ & $14.9-34.7$ & $13.4-26.9$ & 33 & - & - & 35 & 2 & - & 13 & 1 & - \\
\hline Acer rubrum & 28 & 35 & 161 & 1.1 & 1.3 & 6.1 & $1.7-39.0$ & $1.2-44.9$ & $0.5-56.1$ & 11 & 13 & 74 & 12 & 19 & 83 & 5 & 2 & 3 \\
\hline Acer saccharum & 117 & 44 & 51 & 4.4 & 1.8 & 1.9 & $0.6-72.0$ & $0.7-47.5$ & $1.2-59.0$ & 92 & 28 & 26 & 21 & 12 & 21 & 4 & 4 & 4 \\
\hline Betula alleghaniensis & 42 & 34 & 22 & 1.6 & 1.3 & 0.8 & $1.3-40.0$ & $2.0-29.0$ & $9.0-36.0$ & 18 & 19 & 1 & 21 & 15 & 19 & 3 & - & 2 \\
\hline Betula populifolia & 18 & 17 & 2 & 0.7 & 0.6 & 0.1 & $3.2-15.7$ & $3.7-18.3$ & $12.7-15.9$ & 11 & 9 & - & 7 & 8 & 2 & - & - & - \\
\hline Carpinus caroliniana & - & 61 & - & - & 2.3 & - & - & $0.9-12.3$ & - & - & 59 & - & - & 2 & - & - & - & - \\
\hline Fraxinus nigra & 74 & 95 & 66 & 2.8 & 3.6 & 2.5 & $1.2-42.6$ & $1.0-25.3$ & $1.2-11.8$ & 41 & 70 & 65 & 31 & 25 & 1 & 2 & - & - \\
\hline Fraxinus pennsylvanica & 252 & 76 & 8 & 9.6 & 2.9 & 0.3 & $0.2-58.4$ & $0.4-52.9$ & $0.4-40.0$ & 174 & 20 & 19 & 79 & 2 & 4 & 13 & - & - \\
\hline Pinus strobus & - & - & 31 & - & - & 1.2 & - & - & $2.0-66.2$ & - & - & 1 & - & - & 8 & - & - & 22 \\
\hline Populus tremuloides & 67 & 18 & 11 & 2.5 & 0.7 & 0.4 & $1.8-21.5$ & $7.3-37.2$ & $4.0-37.6$ & 60 & 3 & 2 & 7 & 10 & 6 & 0 & 5 & 3 \\
\hline Prunus serotina & 71 & 45 & 14 & 2.7 & 1.7 & 0.5 & $0.9-39.0$ & $2.7-57.5$ & $5.0-41.0$ & 41 & 8 & 2 & 27 & 30 & 10 & 3 & 7 & 2 \\
\hline Thuya occidentalis & 32 & 10 & 15 & 1.2 & 0.4 & 0.6 & $4.2-36.0$ & $4.7-36.1$ & $7.1-33.5$ & 5 & 2 & 3 & 20 & 5 & 9 & 7 & 3 & 3 \\
\hline Tilia americana & 39 & 13 & - & 1.5 & 0.5 & - & $2.0-54.7$ & $1.30-27.2$ & - & 22 & 6 & - & 16 & 7 & - & 1 & - & - \\
\hline Tsuga canadensis & - & 20 & 123 & - & 0.7 & 4.7 & - & $1.5-18.3$ & $1.2-42.8$ & - & 5 & 45 & - & 15 & 67 & - & - & 11 \\
\hline Ulmus rubra & 56 & 8 & 7 & 2.1 & 0.3 & 0.3 & $0.9-42.2$ & $0.9-29.7$ & $1.6-16.8$ & 38 & 3 & 4 & 17 & 5 & 3 & 1 & - & - \\
\hline Total & 978 & 566 & 869 & - & - & - & - & - & - & 633 & 291 & 484 & 304 & 196 & 348 & 55 & 24 & 51 \\
\hline
\end{tabular}

${ }^{a}$ The relative density is the tree density of each species divided by the total tree density of all species $(n=2633)$ in each flood zones. Note: only the tree species over 25 individuals are counted in this table (see the appendix for the total number of trees identified). 
The Shannon Index also enabled heterogeneity to be determined from one quadrat to another and marked differences to be revealed between the quadrats. The intermediate flood zones appear to be clearly more heterogeneous than the other two zones (Figure 5). In fact, the statistical test revealed significantly higher heterogeneity for the intermediate zones compared to the other two zones. For the latter two zones, however, the analyses obtained with the Shannon Index do not reveal any significantly different values from a statistical standpoint, even though the species composition for each zone is highly different. In the high flood risk zones, species are found that are typical of wetlands such as Fraxinus, including $F$. pennsylvanica and $F$. nigra, whereas species from hydromorphic environments are absent or virtually absent from the no-flood zones, with the latter being characterized by species such as Abies balsamea, Tsuga canadensis and Acer rubrum, which often occupy the upper terraces and prefer mesic conditions [9]. However, it would appear that certain species such as Acer rubrum can tolerate both humid and dry edaphic conditions [9]. Based on our results, however, Acer rubrum seems to prefer mesic conditions (or better drained soils) since it is mainly found outside floodplains (Figure 8 and Table A1). However, topography and drainage are factors that must be considered in the analysis of the composition of the forest cover of floodplains compared to the no-flood zones. In fact, certain studies show that a change in elevation, even of a few meters, is enough to induce a change in the composition of the vegetation cover $[9,58,59]$.

The Principal Coordinate Analysis (PCoA) conducted on all quadrats (94 in total) also reveals marked differences regarding species distribution and composition based on the various study areas (Figure 7). The analysis shows that the high flood risk zones clearly stand out from the other two zones. They are mainly found to the right of Axis 1 and in some places form denser cores with similarities between the quadrats. The no-flood zones are mainly found to the left of Axis 1 and form a central core around Axis 2 . The intermediate flood risk zones are found along Axis 2, and the extent of the cloud joined the other two zones. This reveals a greater diversity of tree species in intermediate flood zones. This is explained by the fact that some tree species are common to the two zones, such as Abies balsamea and Acer saccharum. Also, the disparity between the quadrats along Axis 1 and Axis 2 reveals the importance of environmental factors (e.g., slope, drainage) in the distribution and composition of tree species. Slope and soil moisture conditions seem to play a predominant role, more than soil texture and clay or silt content, which are relatively similar in all the quadrats (Table 2). Besides these abiotic factors (slope and drainage), the effects of shade and light must also be considered, which can also affect the composition (e.g., shade-tolerant species) of the forest cover [9]. Based on the gathered data, the frequent flood zones have more open canopies with a slightly lower tree density (Table 2) than the other two zones studied (MFz and NFz). These more open areas that benefit heliophile species may seem to be characterized by greater tree diversity. Although certain heliophile species such as Populus tremuloides or Prunus serotina are found in a great proportion in frequent flood zones (Table 3), no conclusions can be drawn as to greater species diversity. However, a greater abundance of young trees is noted (tree diameter $<10 \mathrm{~cm}$ ) that possibly benefit from more light (Figure 4a,b).

Lastly, no non-indigenous species of trees was noted in the quadrats that were analyzed, except for Acer negundo, which was found mainly in the high flood risk zones. This non-indigenous species is usually found in disturbed sites, such as near inhabited areas. Note that the sites that experienced the most disturbances are found in the middle section of the Saint-François River. This section is also the one characterized by the most human disturbances (e.g., casual trails or cut trees observed near some of the quadrats). The occurrence of this species in flood zones may be linked to anthropogenic disturbances 
rather than the higher frequency of flooding, or by both phenomena acting concomitantly in these more disrupted environments.

\subsection{Tree Forest Structure}

Regarding the structure of the tree in the quadrats, the trees most frequently observed in the various zones are trees with generally small diameters, ranging from $0.5-13.4 \mathrm{~cm} \mathrm{DBH}$ (minimal values), with a few individuals that may be exceed $30 \mathrm{~cm}$ in diameter (Table 3). Some individuals, such as Fraxinus pennsylvanica, Pinus strobus and Tsuga canadensis, have a higher number of the largest trees. It was also noted that there are many old trees (diameter $>50 \mathrm{~cm}$ ), including red maple (Acer rubrum), Acer saccharum, Fraxinus pennsylvanica, Prunus serotina and Tilia americana, in the quadrats more exposed to flooding (Figure 8), especially in the section of the Saint-François River subject to frequent floods, whereas the lower strata are under-represented (Table 3), and often primarily characterized by a tree stratum. The intermediate zone (MFz) is comparable to the $\mathrm{FFz}$ zone with a high occurrence of small-diameter trees $(<10 \mathrm{~cm})$, which indicates young forest stands. Species such as Fraxinus nigra, Acer saccharum and Carpinus caroliniana, which are representative of these quadrats, often contain more than $60 \%$ of small-diameter individuals.

The no-flood zones are characterized by a greater occurrence of the largest trees (e.g., Pinus strobus and Tsuga canadensis), but these quadrats are made up of individuals with more varied diameters that are more representative of forest tree populations [37]. For instance, many more individuals with intermediate diameters (between 10-30 cm DBH) were noted (Table 3), which indicates relatively variable establishment periods over time and is specific to mature forests [52,53]. The quadrats in the no-flood zones have a forest structure characterized by a higher occurrence of young trees (stems $<10 \mathrm{~cm} \mathrm{DBH}$ ) and trees with intermediate diameters (between 10-30 cm) compared to the cohort of older individuals. The no-flood zones are definitely characterized by a greater occurrence of the largest trees, but these quadrats are made up of individuals with more varied diameters that are more representative of forest tree populations.

Our field observations and the various measurements performed over the last years $[35,36,48]$ show that the sediments deposited after the river freshet, which are mainly formed by silt or fine sand, can reach thicknesses of $0.5-4.5 \mathrm{~cm}$ on average. These sedimentary deposits are sufficient to hinder the normal growth of the saplings established early in the season (May and June) and could even cause their mortality. In addition, if there are heavy floods, these saplings cannot withstand the currents and could be pulled out of the ground. Photograph B (Figure 2) clearly shows the strength of the river current (summer flood in late August 2011 in the Richmond area) that caused substantial damage to ferns (Matteuccia struthiopteris) and which, combined with the freshet, left several centimeters of silt (4-5 cm in thickness) on the terrace shelf. These phenomena, which can occur once or twice during the growing season, can considerably hinder seedling regeneration and maintenance.

Moreover, field observations showed a lower rate of regeneration (no annual saplings) of the tree stratum in high flood zones (FFz), while a higher recruitment rate is found in the MFz zones and no-flood zones [37]. We can assume that the low recruitment rate in frequent flood zones is explained by the higher flood frequency, which prevents annual shoots from being maintained and causes a drop in the survival rate of the saplings in subsequent years [26,28,37]. As floods can occur once or twice a year (spring and fall), young shoots have a lesser chance of survival. The saplings, in fact, are at risk of 
being rooted up and carried away by the current. A strong river flow can also cause sediment mobilization, which affects plant germination and establishment. The inflow of sediment during floods can also completely cover the year's saplings and this can damage or destroy the young shoots.

Lastly, the edaphic data collected in the different quadrats particularly show marked differences between the flood and no-flood zones (Table 2). For instance, the soil acidity in FFz is characterized by slightly more acidity, but comparable to the MFz, whereas soil acidity is higher in the no-flood zones $(\mathrm{NFz})$. Also, the soils outside the flood zones have generally the lowest $\mathrm{pH}$ values, which can be explained by the presence of ground biomass (litter) on the forest floor. The litter and decomposition of organic debris produces organic compounds that can acidify the soils and thus reduce soil $\mathrm{pH}$ [60].The no-flood zones have also significantly thicker litter (3-4 cm on average) compared with the frequent flood zones. When all the soil properties are compared based on the study areas (MAS and STF sectors), the most marked differences among the three zones mainly pertain to textural variations, soil $\mathrm{pH}$ levels, and soil biomass thicknesses, which are all significantly greater in the no-flood zones. Furthermore, the drainage conditions and topography are significantly different in the no-flood zones with generally steeper slopes $(>10 \%)$, which favour better soil drainage (Table 2). All of these environmental factors must be considered in the composition of the forest cover. Species such as ash ( $F$. pennsylvanica and $F$. nigra) prefer wetlands, which explains their considerable abundance in these environments (Figures 7 and 8). Lastly, the presence of thick soil biomass (litter) observed in the NFz zones definitely favours seed germination, whereas in the areas where there is no litter, as can be observed in several frequent flood zones, germination is more compromised. The absence or virtual absence of litter in the frequent flood zones is largely due to the loss of biomass transported by the strong currents during spring floods, or even later in the year with floods in the summer or fall (see Figure 4b). These floods, which can occur repeatedly during the growing season, can considerably hinder sapling vitality and even survival and, by the same token, affect species establishment efforts over the long term.

\section{Conclusions}

This study aims at better understanding the dynamics of forest ecosystems affected by frequent floods that have increased in recent decades in the southern part of Québec. A marked difference is noted in the composition and diversity of forests for the various zones under study (FFz, MFz and NFz), especially those subject to frequent flooding (interval of 0-20 years). The zone less subject to flooding (interval of 20-100 years) is characterized by greater diversity in tree species and appears to benefit from its intermediate situation (hydrological gradient) and share the diversity of the tree species among the two other zones (FFz and NFz).

Although it is difficult to predict with certainty the direct impacts of an increase in flood frequency in the forest areas being studied, it was noted that an increase in floods on a local scale modifies the composition of quadrats that are characterized by a strong representation of certain species in favor of all others and a lower diversity of species compared with the intermediate zone. Moreover, a low representation of medium- and large-diameter trees was noted in the frequent flood zones. For certain quadrats, the lack or virtual lack of tree cohorts with intermediate diameters (e.g., 20-30 cm) undoubtedly points to the difficulty that forest stands have of regenerating and maintaining themselves. 
Riparian forests in the flood zones with a recurrence interval of $0-20$ yrs are found to also have a low rate of regeneration, which can be explained by several factors, including high flood frequency. Moreover, strong currents during the floods and floodplain aggradation also reduce the establishment of seedlings and survival rates. These factors could gradually transform the composition and diversity of riparian forest ecosystems and lead to a loss of diversity and productivity for these tree populations. Besides flood recurrence, other factors must be considered in order to understand the dynamics of these riverside forests: interspecies competition, soil conditions, the establishment of exotic species, favored by the opening of the canopy, for instance, along with human disturbances. These various factors combined with the impact of successive floods make these particular riverside forests especially vulnerable and could cause them to experience a progressive decline.

\section{Acknowledgments}

We would like to thank NSERC (Natural Sciences and Engineering Research Council of Canada) for financial support of this research (RGPIN-2001-2016). Thanks also Dominic Savoie, Claudine Ouellet, Lorraine Pelletier, Ilias Bazier for their field assistance.

\section{Author Contributions}

The field work was conducted by Jean-Sébastien Berthelot, Diane Saint-Laurent and Vernhar Gervais-Beaulac. The paper was written by Jean-Sébastien Berthelot and Diane Saint-Laurent, and data compilation and statistical analyzes were realized by Jean-Sébastien Berthelot and Aurélien Présent, with help of the other authors.

\section{Appendix}

Table A1. All tree species identified in the 94 quadrats $(10 \mathrm{~m} \times 20 \mathrm{~m})$ in the three zones (FFz, MFz and NFz).

\begin{tabular}{|c|c|c|c|c|c|c|c|c|c|}
\hline Tree Species & $\begin{array}{c}\text { Species } \\
\text { Code }\end{array}$ & Tota & Tree & tems & Tree Species & $\begin{array}{c}\text { Species } \\
\text { Code }\end{array}$ & Tot & Tree & tems \\
\hline $\begin{array}{c}\text { and } \mathrm{MFz} \text { ) and no-flood } \\
\text { zones (NFz) }\end{array}$ & & $\mathrm{FFz}$ & $\mathrm{MFz}$ & $\mathrm{NFz}$ & & & $\mathrm{FFz}$ & $\mathrm{MFz}$ & $\mathrm{NFz}$ \\
\hline Abies balsamea (L.) Mill. & ABBA & 101 & 87 & 358 & Ostrya virginiana Mill. & OSVI & - & 3 & 13 \\
\hline Acer negundo L. & ACNE & 81 & 3 & - & Picea glauca (Moench) & PIGL & - & 4 & 1 \\
\hline Acer saccharinum $\mathrm{L}$. & ACRI & 16 & 1 & - & Picea mariana (Mill.) & PIMA & 1 & 1 & 3 \\
\hline Acer rubrum L. & ACRU & 28 & 35 & 161 & Picea rubens Sarg. & PIRU & - & 9 & 9 \\
\hline Acer saccharum Marsh. & ACSA & 117 & 44 & 51 & Pinus strobus L. & PIST & - & - & 31 \\
\hline Betula alleghaniensis Britt. & BEAL & 42 & 34 & 22 & Populus balsamifera $\mathrm{L}$. & POBA & 3 & 7 & - \\
\hline
\end{tabular}


Table A1. Cont.

\begin{tabular}{|c|c|c|c|c|c|c|c|c|c|}
\hline Tree Species & $\begin{array}{l}\text { Species } \\
\text { Code }\end{array}$ & Total & Tree & tems & Tree Species & $\begin{array}{l}\text { Species } \\
\text { Code }\end{array}$ & Total & Tree & tems \\
\hline Betula papyrifera Marsh. & BEPA & 2 & 4 & 13 & Populus deltoides Bartr. & PODE & 1 & 4 & 3 \\
\hline Betula populifolia Marsh. & BEPO & 18 & 17 & 2 & $\begin{array}{c}\text { Populus grandidentata } \\
\text { Michx. }\end{array}$ & POGR & 3 & 4 & 6 \\
\hline Carpinus caroliniana Walt. & CACA & - & 61 & - & $\begin{array}{c}\text { Populus tremuloides } \\
\text { Michx. }\end{array}$ & POTR & 67 & 18 & 11 \\
\hline Cornus altenifolia $\mathrm{L}$. & COAL & 3 & - & - & Prunus serotina Ehrh. & PRSE & 71 & 45 & 14 \\
\hline Corylus cornuta Marsh. & $\mathrm{COCO}$ & - & 2 & - & Quercus rubra $\mathrm{L}$. & QURU & - & 9 & 3 \\
\hline Fagus grandifolia Ehrh. & FAGR & 1 & 13 & 10 & Salix sp. & SALI & 3 & 1 & - \\
\hline Fraxinus americana $\mathrm{L}$. & FRAM & - & 11 & 5 & Thuja occidentalis L. & THOC & 32 & 10 & 15 \\
\hline Fraxinus nigra Marsh. & FRNI & 74 & 95 & 66 & Tilia americana $\mathrm{L}$. & TIAM & 39 & 13 & - \\
\hline $\begin{array}{c}\text { Fraxinus pennsylvanica } \\
\text { Marsh. }\end{array}$ & FRPE & 252 & 76 & 8 & $\begin{array}{c}\text { Tsuga canadensis (L.) } \\
\text { Carr. }\end{array}$ & TSCA & 0 & 20 & 123 \\
\hline Juglans cinerea $\mathrm{L}$. & JUCI & - & 1 & - & Ulmus americana L. & ULAM & 6 & 5 & - \\
\hline $\begin{array}{l}\text { Larix laricina } \\
\text { (Du Roi) Koch }\end{array}$ & LALA & 2 & 3 & - & Ulmus rubra Mühl. & ULRU & 56 & 8 & 7 \\
\hline Malus pumila Mill. & MAPU & 4 & - & - & Unknown & UKN & 10 & 5 & 12 \\
\hline Total of trees & & 741 & 487 & 696 & & & 292 & 166 & 251 \\
\hline Number of tree species & & 14 & 16 & 10 & & & 12 & 17 & 14 \\
\hline
\end{tabular}

\section{Conflicts of Interest}

The authors declare no conflict of interest

\section{References}

1. Amoros, C.; Bornette, G.; Henry, C. A vegetation-based method for ecological diagnosis of riverine wetlands. Environ. Manag. 2000, 25, 211-227.

2. Palmer, M.A.; Lettenmaier, D.P.; Poff, N.L.; Postel, S.L.; Richter, B.; Warner, R. Climate change and river ecosystems: Protection and adaptation options. Environ. Manag. 2009, 44, 1053-1068, doi:10.1007/s00267-009-9329-1.

3. Cooper, D.J.; Andersen, D.C.; Chimner, R.A. Multiple pathways for woody plant establishment on floodplains at local to regional scales. J. Ecol. 2003, 91, 182-196, doi:10.1046/j.13652745.2003.00766.x.

4. Blöschl, G.; Ardoin-Bardin, S.; Bonell, M.; Dorninger, M.; Goodrich, D.; Gutknecht, D.; Matamoros, D.; Merz, B.; Shand, P.; Szolgay, J. At what scales do climate variability and land cover change impact on flooding and low flows? Hydrol. Proc. 2007, 21, 1241-1247.

5. Eckhardt, K.U.; Ulbrich, U. Potential impacts of climate change on groundwater recharge and streamflow in a central European low mountain range. J. Hydrol. 2003, 284, 244-252.

6. Van der Nat, D.; Tockner, K.; Edwards, P.J.; Ward, J.V.; Gurnell, A.M. Habitat change in braided flood plains (Tagliamento, NE-Italy). Fresh Biol. 2003, 48, 1799-1812; doi:10.1046/ j.1365-2427.2003.01126.x. 
7. Barnett, T.P.; Pierce, D.W.; Hidalgo, H.G.; Bonfils, C.; Santer, B.D.; Das, T.; Bala, G.; Wood, A.W.; Nozawa, T.; Mirin, A.A.; et al. Human-induced changes in the hydrology of the western United States. Science 2008, 319, 1080-1083; doi:10.1126/science.1152538.

8. Camporeale, C.; Perucca, E.; Ridolfi, L.; Gurnell. A.M. Modeling the interactions between river morphodynamics and riparian vegetation. Rev. Geophr. 2013, 51, 379-414.

9. Battaglia, L.L.; Sharitz, R.R. Responses of floodplain forest species to spatially condensed gradients: A test of the flood-shade tolerance trade off hypothesis. Oecologia 2006, 147, 108-118.

10. Bornette, G.; Tabacchi, E.; Hupp, C.; Puijalon, S.; Rostan, J.C. A model of plant strategies in fluvial hydrosystems. Fresh. Biol. 2008, 53, 1692-1705.

11. Ward, J.V.; Tockner, K.; Arscott, D.B.; Claret, C. Riverine landscape diversity. Fresh. Biol. 2002, 47, 517-539.

12. Bendix, J.; Cowell, C.M. Disturbance and riparian tree establishment in the Sespe Wilderness, California, USA. Phys. Geogr. 2013, 34, 149-158.

13. Rodríguez-González, P.M.; Campelo, F.; Albuquerque, A.; Rivaes, R.; Ferreira, M.T.; Santos Pereira, J. Sensitivity of black alder (Alnus glutinosa [L.] Gaertn.) growth to hydrological changes in wetland forests at the rear edge of the species distribution. Plant Ecol. 2014, 215, 233-245.

14. Mouw, J.E.B.; Stanford, J.A.; Alaback, P.B. Influences of flooding and hyporheic exchange on floodplain plant richness and productivity. River Res. Appl. 2009, 25, 929-945; doi:10.1002/rra.1196.

15. Charron, I.; Johnson, E.A. The importance of fires and floods on tree ages along mountainous gravel-bed streams. Ecol. Appl. 2006, 16, 1757-1770.

16. Turner, M.G.; Gergel, S.E.; Dixon, M.D.; Miller, J.R. Distribution and abundance of trees in floodplain forests of the Wisconsin River: Environmental influences at different scales. J. Veg. Sci. 2014, 15, 729-738.

17. Rivaes, R.P.; Rodriguez-Gonzalez, P.M.; Ferreira, M.T.; Pinheiro, A.N.; Politti, E.; Egger, G.; Garcia-Arias, A.; Frances, F. Modeling the evolution of riparian woodlands facing climate change in three European rivers with contrasting flow regimes. PLOS ONE 2014, 9, e110200.

18. Gilvear, D.; Willby, N. Channel dynamics and geomorphic variability as controls on gravel bar vegetation, River Tummel, Scotland. River Res. Appl. 2006, 22, 457-474; doi:10.1002/rra.917.

19. Pollock, M.; Naiman, R.; Hanley, T. Plant species richness in riparian wetlands-a test of biodiversity theory. Ecology 1998, 79, 94-105.

20. Bendix, J. Stream power influence on southern Californian riparian vegetation. J. Veg. Sci. 1999, 10, 243-252; doi:10.2307/3237145.

21. Nilsson, C.; Grelsson, G.; Johansson, M.; Sperens, U. Patterns of plant species richness along riverbanks. Ecology 1989, 70, 77-84.

22. Cook, H.F. Floodplain nutrient and sediment dynamics on the Kent Stour. J. Water Environ. 2007, 21, 173-181.

23. Bailey, S.E.; Guimond, J.K. Aboveground biomass and nutrient limitation in relation to river connectivity in Montane floodplain marshes. Wetlands 2009, 29, 1243-1254.

24. Brovelli, A.; Batlle-Aguilar, J.; Barry, D.A. Analysis of carbon and nitrogen dynamics in riparian soils: Model development. Sci. Total Environ. 2012, 429, 231-245.

25. Rokosch, A.E.; Bouchard, V.; Fennessy, S.; Dick, R. The use of soil parameters as indicators of quality in forested depressional wetlands. Wetlands 2009, 29, 666-677. 
26. Asaeda, T.; Pattiyage, I.; Gomes, A.; Takeda, E. Spatial and temporal tree colonization in a midstream sediment bar and the mechanisms governing tree mortality during a flood event. River Res. Appl. 2010, 26, 960-976.

27. Barrett, R.; Nielsen, D.L.; Croome, R. Association between the plant between the plant communities of floodplain wetlands, water regime and wetland type. River Res. Appl. 2010, 26, 866-876.

28. Hamdan, M.A.; Asada, T.; Hassan, F.M.; Warner, B.G.; Douabul, A.A.; al-Hilli, M.R.A.; Alwan, A.A. Vegetation response to Re-flooding in the Mesopotamian Wetlands, South Irak. Wetlands 2010, 30, 177-188.

29. Bendix, J.; Hupp, C.R. Hydrological and geomorphological impacts on riparian plant communities. Hydrol. Proces. 2000, 14, 2977-2990.

30. Tanentzap, A.J.; Lee, W.G.; Schulz, K.A.C. Niches drive peaked and positive relationships between diversity and disturbance in natural ecosystems. Ecosphere 2013, 4, 133.

31. Roxburgh, S.H.; Shea, K.; Wilson, J.B. The intermediate disturbance hypothesis: Patch dynamics and mechanisms of species coexistence. Ecology 2004, 85, 359-371.

32. Friedman, J.M.; Auble, G.T.; Andrews, E.D.; Kittel, G.; Madole, R.F.; Griffin, E.R.; Allred, T.M. Transverse and longitudinal variation in woody riparian vegetation along a Montane River. West North Am. Nat. 2006, 66, 78-91.

33. Hupp, C.R.; Rinaldi, M. Riparian vegetation patterns in relation to fluvial landforms and channel evolution along selected rivers of Tuscany (Central Italy). Ann. Assoc. Am. Geogr. 2007, 97, 12-30; doi:10.1111/j.1467-8306.2007.00521.x.

34. Franklin, S.C.; Kupfer, J.A.; Pezeshki, S.R.; Gentry, R.; Smith, R.D. Complex effects of channelization and levee construction on western Tennessee floodplain forest function. Wetlands 2009, 29, 451-464.

35. Drouin, A.; Saint-Laurent, D.; Lavoie, L.; Ouellet, C. High-Precision elevation model to evaluate the spatial distribution of soil organic carbon in active Floodplains. Wetlands 2011, 31, 1151-1164; doi:10.1007/s13157-011-0226-z.

36. Saint-Laurent, D.; Lavoie, L.; Drouin, A.; St-Laurent, J.; Ghaleb, B. Floodplain sedimentation rates, soil properties and recent flood history in southern Québec. Glob. Planet. Chang. 2010, 70, 76-91; doi:10.1016/j.gloplacha.2009.11.009.

37. Berthelot, J.S. Structure et Évolution des Peuplements Riverains en Fonction des Zones de Récurrence D'inondation (Bassin Centre-sud du Québec). Master's Thesis, Département des Sciences de l'Environnement, Université du Québec à Trois-Rivières, Québec, QC, Canada, 2014.

38. EC-MEF (Environment Canada and Ministry of Environment of Québec). Flood Risk Map : Saint-François River, Quebec. Government of Canada and Ministry of Environment, Québec. Designated areas as subject to recurrent and severe flooding. 1982. Available online: http://www.ec.gc.ca/eau-water/default.asp?lang=En\&n=09DACE2F-1 (accessed on 7 March 2014).

39. CEHQ (Centre D'expertise Hydrique du Québec) (2013) Cartographie des Zones de Risques d'inondation. Ministère du Développement Durable, de la Faune et des Parcs. 2013. Available online: (http://www.cehq.gouv.qc.ca/zones-inond/cartographie/ (accessed on 12 March 2014).

40. Lavoie, L.; Saint-Laurent, D.; St-Laurent, J. Pedological and sedimentological analyses of alluvial soils and paleosols on floodplain terraces. Can. J. Soil Sci. 2006, 86, 813-826. 
41. Castonguay, S.; Saint-Laurent, D. Reconstructing Reforestation: Changing Land Use Patterns along the Saint-François River in the Eastern Townships. In Method and Meaning in Canadian Environmental History; MacEachern, A., Turkel, E.J., Eds.; Th. Nelson: Toronto, ON, Canada, 2009; pp. 273-292.

42. Bélanger, D.; Grenier, F.; Poulin, C. Évolution de la Rivière Saint-François par le Profil, l'occupation des Rives, la Sédimentation et l'érosion; Rapport d'analyse et documents cartographiques; Université de Sherbrooke: Sherbrooke, QC, Canada, 2001; p. 35.

43. Desmeules, J. Bassin Versant de la Saint-François: Ressources Humaines; Ministère des Richesses naturelles, Direction Générale des Eaux: Québec, QC, Canada, 1977; p. 98.

44. PRDITT (Plan Régional de Développement Intégré des Ressources Naturelles et du Territoire). Portrait de la Forêt Naturelle du Centre-du-Québec. Available online: http://www.cre.centre-duquebec.qc.ca/client/uploads/317/103942213210642.pdf (accessed on 10 April 2014).

45. Ville de Sherbrooke. Schéma D’aménagement et de Développement Révisé. Règlement no. 875, Avril 2013. Available online: http://www.ville.sherbrooke.qc.ca/fileadmin/fichiers/Planification /Sch\%C3\%A9ma\%20-\%20Version\%2015\%20avril\%20adopt\%C3\%A9e.pdf (accessed on 16 September 2014).

46. Cogesaf (Conseil de Gouvernance de l'eau des Bassins Versants de la Rivière Saint-François). Analyse du Bassin Versant de la Rivière Saint-François. 2006. Available online: http://cogesaf.qc. ca/analyse-du-bassin-versant-de-la-riviere-saint-francois/ (accessed on 20 September 2014).

47. Government of Canada. Canadian System of Soil Classification, 3rd ed.; Soil Classification Working Group, Research Branch, Agriculture and Agri-Food Canada, Publication 1646; Government of Canada: Ottawa, ON, Canada, 1998.

48. Saint-Laurent, D.; Gervais-Beaulac, V.; Berthelot, J.S. Variability of soil properties in different flood-risk zones and link with hydroclimatic changes (Southern Québec, Canada). Geoderma 2014, 214-215, 80-90; doi:10.1016/j.geoderma.2013.09.025.

49. Saint-Laurent, D.; Mesfioui, M.; Evin, G. Hydroclimatic variability and relation with flood events (Southern Québec, Canada). Water Res. 2009, 36, 43-56; doi:10.1134/S0097807809010047.

50. R Development Core Team. A Language and Environment for Statistical Computing; R Foundation for Statistical Computing: Vienna, Austria, 2011.

51. Biswas, S.R.; Mallik, A.U. Disturbance effects on species diversity and functional diversity in riparian and upland plant communities. Ecology 2010, 91, 28-35.

52. Lorimer, C.G. Age structure and disturbance history of a southern Appalachian virgin forest. Ecology 1980, 61, 1169-1184.

53. Frey, B.R.; Ashton, M.S.; McKenna, J.J.; Ellum, D.; Finkral, A. Topographic and temporal patterns in tree seedling establishment, growth, and survival among masting species of southern New England mixed-deciduous forests. For. Ecol. Manag. 2007, 245, 54-63; doi:10.1016/j.foreco.2007.03.069.

54. Stella, J.C.; Battles, J.J.; Orr, B.K.; McBride, J.R. Synchrony of seed dispersal, hydrology and local climate in a semi-arid river reach in California. Ecosystems 2006, 9, 1200-1214.

55. Mahoney, J.M.; Rood, S.B. Streamflow requirements for cottonwood seedling recruitment-An integrative model. Wetlands 1998, 18, 634-645.

56. Denslow, J.S.; Battaglia, L.L. Stand composition and structure across a changing hydrologic gradient: Jean Lafitte National Park. Wetlands 2002, 22, 738-752. 
57. Wharton, C.H.; Kitchens, W.M.; Pendleton, E.C.; Sipe, T.W. The ecology of bottomland hardwood swamps of the southeast: A community profile. FWS/OBS 1982, 81, 37.

58. Goodburn, J.M.; Lorimer, G.G. Population structure in old-growth and managed northern hardwoods: An examination of the balanced diameter distribution concept. For. Ecol. Manag. 1999, 118, 11-29.

59. Foster, D.R. Disturbance history, community organization and vegetation dynamics of the old-growth Pisgah forest, southwestern New Hamphire, USA. J. Ecol. 1988, 76, 105-134.

60. Brady, N.C.; Weil, R.R. The Nature and Properties of Soils, 14th ed.; Prentice Hall: Upper Saddle River, NJ, USA, 2007.

(C) 2015 by the authors; licensee MDPI, Basel, Switzerland. This article is an open access article distributed under the terms and conditions of the Creative Commons Attribution license (http://creativecommons.org/licenses/by/4.0/). 